\title{
SEVERNÍ ČÁST MALÉ HANÉ V ARCHEOLOGICKÝCH PRAMENECH 11.-13. STOLETÍ ZÍSKANÝCH POVRCHOVOU PROSPEKCÍ
}

\section{DAVID VÍCH}

\begin{abstract}
Abstrakt: Povrchová prospekce Malé Hané přinesla nálezy keramiky a nevelký soubor kovových předmětů. Ve shodě s písemnými prameny zde potvrdila přitomnost člověka v 11.-13. století. Rozsah osidlení v 11.-12. století kopíruje starší situaci ze středni doby hradištní, k rozmachu osídleného území došlo až ve 13. století.
\end{abstract}

Klíčová slova: raný středověk - mladši doba hradištní-13. století-Malá Haná-povrchová prospekce.

The northern part of the Malá Haná region in archaeological sources from the 11th-13th century yielded by surface prospecting

Abstract: Surface prospecting in the Malá Haná region yielded finds of pottery and a small series of metal objects. In accord with written sources, it confirmed human presence in the 11th-13th century. The extent of settlement in the 11th-12th century copied the situation from the Middle Hillfort period; the settlement area was only expanded in the 13th century.

Key words: early Middle Ages - Late Hillfort period - 13th century - Malá Haná - surface prospecting.

\section{1 Úvod}

V roce 2008 byl publikován a vyhodnocen soupis nálezů sběrového charakteru od časně slovanského období po střední dobu hradištní z Malé Hané, jen v omezené míře byla v textu věnována pozornost mladší době hradištní. Zevrubnější pozornosti se dostalo pouze všem tehdy dostupným nálezům z mařínského hradiska uloženým v Městském muzeu v Moravské Třebové (k. ú. Zadní Arnoštov a Křenov, okr. Svitavy, Pardubický kraj, Profantová-Vích 2008). Ač v souladu s touto starší sídelní tradicí a s výpovědí písemných pramenů je pro 11.-13. století přítomnost člověka na Malé Hané nade vší pochybnost, výpověd' pramenů archeologických až dosud v této věci silně zaostávala (přehled viz Procházka 2014). Následující řádky věnované jak povrchovým sběrům, tak i výsledkům detektorové prospekce si kladou za cíl dosavadní obraz osídlení severní části Malé Hané v mladším úseku raného středověku alespoň v omezené míře doplnit. ${ }^{1}$

\section{Písemné prameny}

Do písemných pramenů proniká zájmové území ve druhé polovině 11. století. Poprvé se tak stalo roku 1078 zakládací listinou kláštera Hradiště u Olomouce založeného Otou I. Sličným a jeho Ženou Eufemií, kteří darovali klášteru dvorec Úsobrno s př́íslušejícími osadami a lesem (CDB I, 82-85 č. 79), donaci vzápětí potvrzuje a rozšiřuje český kníže Vratislav II. (CDB I, 85-86 č. 80; k listinám viz Zaoral 1968; Dolista 1971; Bistřický 1993; Wihoda 2002, 35). Dvorec lze snad lokalizovat do prostoru kostelní vyvýšeniny v Knínicích (Doležel 2003, 145-146 s další literaturou), i když nechybí ani názory odlišné (Hradisko u Svitávky, Vávra 1971; Procházka 1994, 234). O které vesnice se jednalo, můžeme pouze spekulovat, protože v textu listiny nejsou explicitně uvedeny (Elbel 2002, 42-44).

$\mathrm{Na}$ počátku roku 1145 došlo podle kronikáře Vincencia $\mathrm{k}$ přepadení olomouckého biskupa Jindřicha Zdíka při cestě do Říma znojemským údělníkem Konrádem u celnice „Uzobren“ (FRB II, 414-415). Stranou přitom ponechme otázku, zda celnice ležela u Jaroměřic

1 Stranou pozornosti zůstávají nálezy ze sídliště pod kostelem sv. Bartoloměje u Jevíčka (tzv. Staré Jevíčko), kterým pro jejich množství a kvalitu musí být věnována samostatná pozornost. Nálezy z okresu Blansko jsou uloženy v Muzeu regionu Boskovicka, nálezy z okresu Svitavy v Regionálním muzeu v Litomyšli a ve Východočeském muzeu v Pardubicích. 
(Šembera 1875, 50-55), na mařínském hradišti (Mackerle 1957), ve Svitávce (Vávra 1971, 98), či jinde (k problematice přepadení Jindřicha Zdíka souhrnně Bolina 2003 s další literaturou). Zmiňme zde alespoň skutečnost, že jako nepravděpodobná se dle dnešního stavu poznatků jeví myšlenka celnice ležící v Hradci nad Svitavou (Čechová 1978, 36-38), protože ten se nachází na území kolonizovaném až v průběhu 13. století. Dosavadní sporadické raně stř̌edověké nálezy z širšího okolí Hradce nad Svitavou souvisí s průběhem dálkové komunikace (Vích 2018).

Důležité informace přináší majetková změna realizovaná tentokráte již premonstráty, kteří na Hradišti nahradili benediktiny, a to získáním území „,curia, que nominatur Vsobren“ (CDB I, 195 č. 208) ztotožňovaného se Svitávkou (k tomu Procházka 1994, 234; Elbel 2002, 49; Doležel 2003, 146).

Ani Malé Hané se pochopitelně nevyhnuly společenské změny třináctého století, pro které zde disponujeme důležitými písemnými prameny.

Nejlépe jsme informováni opět o území v majetku kláštera Hradisko u Olomouce. Z prvořadých pramenů se jedná o listinu opata Roberta z roku 1250 ozřejmující okolnosti založení nové vsi Veličina Lhota (CIB I, 120 č. 40; CDB IV/1, 358-359 č. 197) a podobný pramen, tentokrát opata Budiše, o založení nové vsi Štěpánov (CDB V/2, 357-358 č. 710). Řada informací ohledně hranic knínického zboží patřícího hradišt'skému klášteru a Konicka se dochovala díky sporům, které bylo třeba řešit (podrobně Doležel 2003, 150-152).

Majetkové držby dalších subjektů jsou zde sledovatelné již podstatně hůře. Důležitý pramen představují listiny biskupa Jindřicha Zdíka týkající se přenesení biskupství od kostela sv. Petra ke kostelu sv. Václava v Olomouci a rozšíření biskupské kapituly při novém katedrálním kostele (CDB I, 116-123 č. 115; CDB I, 124-125 č. 116) z roku asi 1141 (k listinám a jejich datování Bistřický 1998; Bolina 1999 s další literaturou). V první tzv. translační listině je uveden výčet více než dvou stovek lokalit, mezi nimiž se opakovaně objevují i Biskupice, v jednom případě považované za Biskupice u Jevíčka (CDB I, 122 č. 115), zaznívají však i názory nesouhlasné (Bolina 2003, 351, poznámka 61). Jako majetek pražského biskupství jsou k roku 1233 uváděny Jaroměřice u Jevíčka (Kristen 1960, 134-135; Čechová 1978, 29).

\section{Soupis lokalit}

Archeologická pramenná základna pochopitelně vznikala dlouhou dobu, na práci předchozích generací (zejména Ferulík 1950; Mackerle 1957a) navázal povrchovými sběry A. Štrof (1979; 1985) a od roku 1997 autor. To se projevilo i na stavu poznání regionu. Zatímco A. Štrof směřoval své aktivity zejména do Lysické sníženiny, povrchové sběry autora se soustřed’ovaly především do severní části Malé Hané. Z uvedeného důvodu je zatím značně podhodnoceno poznání jižní části Malé Hané, tedy Boskovicka, což zdaleka neplatí jenom pro období raného stř̌edověku.

Povrchová prospekce zde co do metodiky navázala na povrchové sběry na Litomyšlsku a Vysokomýtsku, kde každé zjištěné lokalitě byla v rámci jednoho katastrálního území přiřazena jedna číselná řada a sběry se zaměřovaly zejména na typické artefakty (k metodice sběrů viz Vích 2001). Roku 2005 ještě před masovým atakem nelegálních uživatelů detektorů kovů na archeologické lokality na oraných plochách byla zahájena intenzivní prospekce s využitím detektoru kovů cílená především na povrchovými sběry zjištěné sídelní areály (k metodice detektorové prospekce Vích 2015).

Následující řádky podávají základní informace o zjištěných lokalitách závěru raného středověku severní části Malé Hané. ${ }^{2}$

2 Zevrubné informace o lokalizaci, okolnostech povrchových sběrů, jejich frekvenci atd. najde zájemce na stránkách př́islušných čísel Zpravodaje východočeského muzea v Hradci Králové a Archeologie východnich Čech. 


\section{Biskupice $3 a, 3 b$}

nálezy: mladší doba hradištní? (ojedinělý střep), RS/VS-VS ${ }^{3}$ (keramika - XX); doprovodné aktivity: sídliště kultury s lineární keramikou, pohřebiště (?) doby popelnicových polí; přírodní podmínky: terasa nad inundací Jevíčky, hlinitá půda, 328-336 m n. m.

\section{Biskupice 4c}

nálezy: střední-mladší doba hradištní (keramika - XX, skleněná perla); doprovodné aktivity: ojedinělá neolitická a eneolitická broušená industrie, sídliště doby popelnicových polí, doby laténské a doby římské; prrírodní podmínky: svah nad inundací Jevíčky, hlinitá půda, 332-338 m n. m.

\section{Boršov}

nálezy: RS/VS (bronzová přezka); doprovodné aktivity: velmi sporadické nálezy doby římské; přírodní podmínky: terénní hřbet mezi Stříbrným potokem a jeho bezejmenným levobřežním přítokem, písčitohlinitá půda, $430 \mathrm{~m} \mathrm{n}$. $\mathrm{m}$.

\section{Cetkovice 1}

nálezy: střední-mladší doba hradištní (keramika - XX); doprovodné aktivity: sídliště s nečetnými nálezy doby popelnicových polí a doby římské; přírodní podmínky: mírná vyvýšenina v inundaci Uhřického potoka, hlinitá půda, $384-388 \mathrm{~m} \mathrm{n}$. $\mathrm{m}$.

\section{Cetkovice 3}

nálezy: stř̌ední-mladší doba hradištní (keramika - XX); doprovodné aktivity: ojedinělá keramika kultury s lineární keramikou, sídliště doby laténské, ojedinělá keramika doby halštatské a mladší doby římské; přírodní podmínky: svah nad bezejmennou vodotečí, hlinitá půda, 376-388 m n. m.

\section{Drválovice 1 - Kambovo pole}

nálezy: střední-mladší doba hradištní (keramika - XX); doprovodné aktivity: předneolitická štípaná industrie, sídliště kultury s lineární keramikou; prŕrodní podmínky: svah nad bezejmennou vodotečí, hlinitá půda, 376-388 m n. m.

\section{Chornice 1a, $1 b, 5$}

nálezy: mladší doba hradištní-RS/VS (keramika - XXX, esovité záušnice, mince, olověné kolečko se středovým otvorem, bronzová přezka); doprovodné aktivity: ojedinělá neolitická broušená industrie, časně eneolitické sídliště, sídliště doby popelnicových polí, ojedinělý nález doby laténské); přírodní podmínky: svah při rozhraní Malé Hané a vrchoviny po obou stranách bezejmenné vodoteče, hlinitá půda, 372-400 $\mathrm{m} \mathrm{n}$. $\mathrm{m}$.

3 Použité zkratky: RS/VS - přelom raného a vrcholného středověku (13. století), VS - vrcholný středověk; sumace nálezů - X - jednotlivé kusy, XX - desítky kusů, XXX - stovky kusů. 


\section{Chornice 2c-Lázy $3 c$}

nálezy: RS/VS (keramika - X); doprovodné aktivity: ojedinělá neolitická broušená industrie, sídliště časného eneolitu, doby popelnicových polí, doby laténské, ojedinělé nálezy doby římské; prŕírodní podmínky: po obou stranách drobné př́íležitostné vodoteče, hlinitá půda, $318-350 \mathrm{~m} \mathrm{n}$. $\mathrm{m}$.

\section{Chornice $3 c$}

nálezy: RS/VS (bronzová přezka); doprovodné aktivity: ojedinělá bronzová industrie doby bronzové, sídliště doby laténské; prŕírodní podmínky: severovýchodní svah bez zjevné vazby na vodoteč, $350 \mathrm{~m} \mathrm{n}$. $\mathrm{m}$.

\section{Chornice 6a, $6 \mathrm{~b}$}

nálezy: starší doba hradištní-RS/VS (keramika - XX; kovové artefakty, bronzové přezky, liliovitá opasková kování, zlomek ramene skládacích vážek); doprovodné aktivity: sporadické nálezy doby laténské, sídliště doby rrímské; přírodní podmínky: mírný svah při soutoku potoka Kelímky a říčky Jevíčky, hlinitá půda, 326-338 m n. m.

\section{Chornice 11}

nálezy: střední-mladší doba hradištní (keramika - XX); doprovodné aktivity: ojedinělá atypická pravěká keramika; přírodní podmínky: svah nad říčkou Jevíčkou, hlinitá půda, 322-326 m n. m.

\section{Chornice 16a, $16 \mathrm{~b}$}

nálezy: střední-mladší doba hradištní (keramika - XX); doprovodné aktivity: sporadické neolitické a eneolitické artefakty a nálezy doby popelnicových polí, sídliště doby římské; přírodní podmínky: mírný svah nad soutokem potoka Kelímky s říčkou Jevíčkou, hlinitá půda, 326-330 m n. m.

\section{Chornice 19}

nálezy: RS/VS (opaskové liliovité kování); doprovodné aktivity: ojedinělá neolitická broušená industrie, sporadické časně eneolitické nálezy, sídliště doby popelnicových polí, ojedinělé nálezy doby laténské; prŕírodní podmínky: svah nad potokem, hlinitá půda, 328-346 m n. m.

\section{Jevíčko-předměstí 3}

nálezy: časně slovanské období-RS/VS (keramika - XXX, kovové artefakty, mince, olověná kolečka se středovým otvorem); doprovodné aktivity: sporadické nálezy doby popelnicových polí a doby laténské, sídliště doby římské; prŕírodní podmínky: svah nad Malonínským potokem, hlinitá půda, $342-358 \mathrm{~m} \mathrm{n}$. m.

\section{Jevíčko-předměstí 28}

nálezy: RS/VS (opaskové liliovité kování); doprovodné aktivity: ojedinělá bronzová industrie doby bronzové, sídliště doby římské; přírodní podmínky: svah nad bezejmenným levobřežním přítokem říčky Jevíčky, hlinitá půda, 350-370 m n. m. 


\section{Městečko Trnávka 5}

nálezy: RS/VS (bronzová přezka); doprovodné aktivity: sídliště doby popelnicových polí a doby laténské; př́ŕrodní podmínky: svah nad potokem Oslenka, hlinitá půda, 340-350 m n. m.

\section{Městečko Trnávka 8}

nálezy: RS/VS (keramika - XX); doprovodné aktivity: nezjištěny; př́írodní podmínky: svah nad Heritovským potokem, hlinitá půda, $330 \mathrm{~m} \mathrm{n}$. $\mathrm{m}$.

\section{Petrůvka 1}

nálezy: RS/VS (keramika - X); doprovodné aktivity: pohřebiště (?) doby popelnicových polí; př́írodní podmínky: hřbet nad bezejmennou př́iležitostnou vodotečí, hlinitá půda, 314-325 $\mathrm{m} \mathrm{n}$. m.

\section{Rozstání 2}

nálezy: RS/VS (bronzová přezka); doprovodné aktivity: sídliště doby popelnicových polí; přírodní podmínky: nad soutokem Třebůvky a jejího pravobřežního přítoku, hlinitá půda, 320-322 $\mathrm{m} \mathrm{n}$. m.

\section{Staré Město u Moravské Třebové 8}

nálezy: RS/VS-VS (keramika-XX); doprovodné nálezy: pravěké sídliště (?); př́írodní podmínky: bez zjevné vazby na vodoteč, hlinitá půda, $400 \mathrm{~m} \mathrm{n}$. $\mathrm{m}$.

\section{Unerázka 2}

nálezy: RS/VS (keramika - XX); doprovodné aktivity: paleolitická štípaná industrie, sídliště doby popelnicových polí; přírodní podmínky: svah nad inundací Jevíčky, hlinitá půda, 310-316 m n. m.

\section{Analýza movitých nálezů}

Hlavní část archeologických pramenů tvoří pochopitelně keramika, díky aplikaci detektorů kovů disponujeme i omezeným množstvím kovových předmětů a zcela ojediněle se objeví i sklo. Při zpracování keramiky jsme s ohledem na její sběrový původ odkázáni pouze na některé kvalitativní znaky, zejména pak na výzdobu nádob a tvarování okrajů.

Ve střední Evropě (širší reflexe středoevropského prostoru viz Procházka 2017, 181-240) dochází od druhé poloviny 10. století ke změnám vedoucím ke vzniku mladohradištní keramické produkce, razantnější změny nastupují okolo roku 1000. Obecně s nástupem keramiky mladší doby hradištní dochází na Moravě ke změně tvaru nádob, zejména ke zvýšení úrovně maximální výdutě, postupně se začíná prosazovat keramika dotáčená zcela na hrnčířském kruhu. Kromě ven vyhnutých okrajů nabývajících postupně složitější profilace (protažení hrany, prožlabení) se objevují nové typy okrajů, dále pás vrypů pod hrdlem v kombinaci s vodorovným rýhováním, postupné prosazování výzdoby provedené jednohrotým nástrojem a v některých regionech zřetelný vzestup podílu grafitové keramiky (Staňa 1994, 278-285; Procházka-Peška 2007; Procházka 2009; Balcárková 2013).

Na Malé Hané a Moravskotřebovsku byla dlouho mladší době hradištní věnována pouze okrajová pozornost, což je dáno omezeným množstvím pramenů a nedostatečnými informacemi ohledně nálezových okolností u pramenů dochovaných (v zásadě se jedná o keramiku sběrového charakteru). Souhrnného vyhodnocení se region dočkal nedávno v rámci výše zmíněného zpracování nejstarších dějin Boskovicka (Procházka 2014, 263-272), pro region Moravskotřebovska 
pak s ohledem na omezený počet pramenů není překvapením, že J. Němcová při zpracování keramiky vymezila celý dlouhý úsek let 850-1200 jako společnou 1. fázi (Bolina-Němcová-Šlézar 2008, 54). Situace se díky povrchovým sběrům a v posledních letech i detektorové prospekci mění zejména co do kvantity (Profantová-Vích 2008; Doležel 2007), stratifikovaných souborů bohužel mnohdy stále nedostatečně zpracovaných a publikovaných se však až na výjimky (Procházka-Štrof 1983; Procházka 1984; 1994) stále citelně nedostává. ${ }^{4} \mathrm{Z}$ těchto důvodů se musíme opřít zejména o vyhodnocení situací z nedalekého Mohelnicka, jehož keramická náplň je ostatně keramice z Malé Hané velmi blízká, i když vyhodnocování keramiky tohoto prostoru není prosto určitých problémů (k tomu Procházka 2009, 153; 2017, 184).

Podle poznatků V. Goše (1970; 1977; Goš-Karel 1979; Procházka 1984; Goš-Kapl 1986, 186-198) nejnověji rozvíjených dalšími badateli (Faltýnek-Novák-Šlézar 2018, 134-148; Šlézar-Faltýnek 2019, 183-189) na Mohelnicku v povelkomoravském období masově nastupuje přidávání grafitu do keramické hmoty, které pokračuje dále do 13. století. Nově se objevuje kuželovitě, válcovitě i nálevkovitě seříznuté ukončení okrajů i vytažení spodní i dolní hrany okraje. Starší mladohradištní keramika (tedy v zásadě první polovina 11. století) se vyznačuje různě ukončenými vyhnutými okraji, velkými záseky a hřebenovými vpichy bohatě zdobícími velké nádoby opatřené plastickými lištami, nově se objevují nádoby s válcovitým hrdlem. Po polovině 11. století nastupuje okraj vzhůru vytažený, který postupně převládá a dále se protahuje. Výzdoba sestává z vodorovného rýhování a žlábkování kombinovaného s vlnovkami. Ve 13. století pokračuje převaha grafitu v keramické hmotě, i když už nemusí být tak dominantní, končí protahování vzhůru vytaženého okraje a nastupuje okraj římsovitý, u něhož se postupně začíná prosazovat vnitřní prožlabení, méně často se objeví okraj zesílený a zaoblený. Často se uplatňuje výzdoba pomocí rádélka.

Když pomineme dříve vyhodnocené lokality Cetkovice 1 , Drválovice 1 , Chornice $6 \mathrm{a}, 6 \mathrm{~b}$, Chornice 11, Chornice 16a, 16b a Jevíčko-předměstí 3, disponujeme více než sedmi stovkami zlomků keramiky, ovšem téměř dvě třetiny z tohoto počtu pochází z jediné sídlištní komponenty Chornice 1a, 1b, 5. Z uvedeného celkového množství asi $45 \%$ připadá na keramiku typickou. Okraje tvoří $17 \%$ z celkového počtu zlomků a $40 \%$ z podílu typických zlomků, zbytek typických zlomků připadá na podhrdlí a zdobená těla nádob. Vzhledem ke způsobu sběrů, kdy atypické zlomky byly sbírány pouze na počátku při objevení lokality a později zůstaly ponechány na místě nálezu, tato čísla spíš než o raně středověké keramické produkci podávají představu o způsobu sběrů. Navíc v posledních letech s rostoucím počtem nasbírané keramiky byl stejný přístup aplikován i na typické střepy a do muzejních sbírek se dostávaly již jen ojedinělé zlomky prrinášející zcela nové kvalitativní poznatky. Ze stejných důvodů podobně zamlžená zůstane i snaha po zjištění procentuálního podílu grafitové keramiky, kdy navíc $\mathrm{v}$ př́ípadě atypické keramiky je nezřídka obtížné identifikovat možnou starší intruzi zejména z doby laténské. Lze proto pouze konstatovat, že se na základě povrchových sběrů jeví podíl grafitové keramiky v souborech mladší doby hradištní až počátku vrcholného středověku jako naprosto dominantní. Pokud není do keramického těsta přidán grafit, jedná se obvykle o redukčně pálený střep nezřídka s př́iměsí slídového ostřiva. Ve sběrovém souboru ze zájmového území jsme vedle masově se vyskytujících hrnců schopni rozpoznat ještě pokličky (obr. 3:19, 20, nejspíše i 1:6) a zásobnice (obr. 1:1; 2:1, 4, 5).

Okraje jsou nejčastěji ukončeny zaobleně, běžně se objeví i vodorovné seříznutí. Další typy ukončení okrajů jako kuželovité a nálevkovité seříznutí, prožlabení či římsovité ukončení jsou ve výrazné menšině. V tvarech okrajů se setkáváme s okraji ven vykloněnými různě ukončenými (Biskupice 3a, obr. 3:23; Biskupice 4c, obr. 3:2; Drválovice 1 - Kambovo pole, obr. 3: 10; Chornice 1a, obr. 1:20). Velmi často se setkáváme s vytaženými okraji, a to jak s nízkými (Chornice 1a, 1b, 5, obr. 1:12, 23, 24; 2:6, 27; Biskupice 4c, obr. 3:1), tak i protaženými, nezř́íka s lištou (Chornice 1a, 1b, 5, např. obr. 1:9, 13, 14; 2:9, 16, 17, 20). Neméně běžné jsou římsovité

4 Důsledkem tohoto stavu je zdánlivá absence pohřebišt', a to nikoliv pouze jen těch raně středověkých. Značný potenciál pro poznání sídlišt’ si uchovávají prakticky nevyužité výsledky výzkumů ze stavby dálnice Vratislav - Vídeň z doby nacistické okupace. 

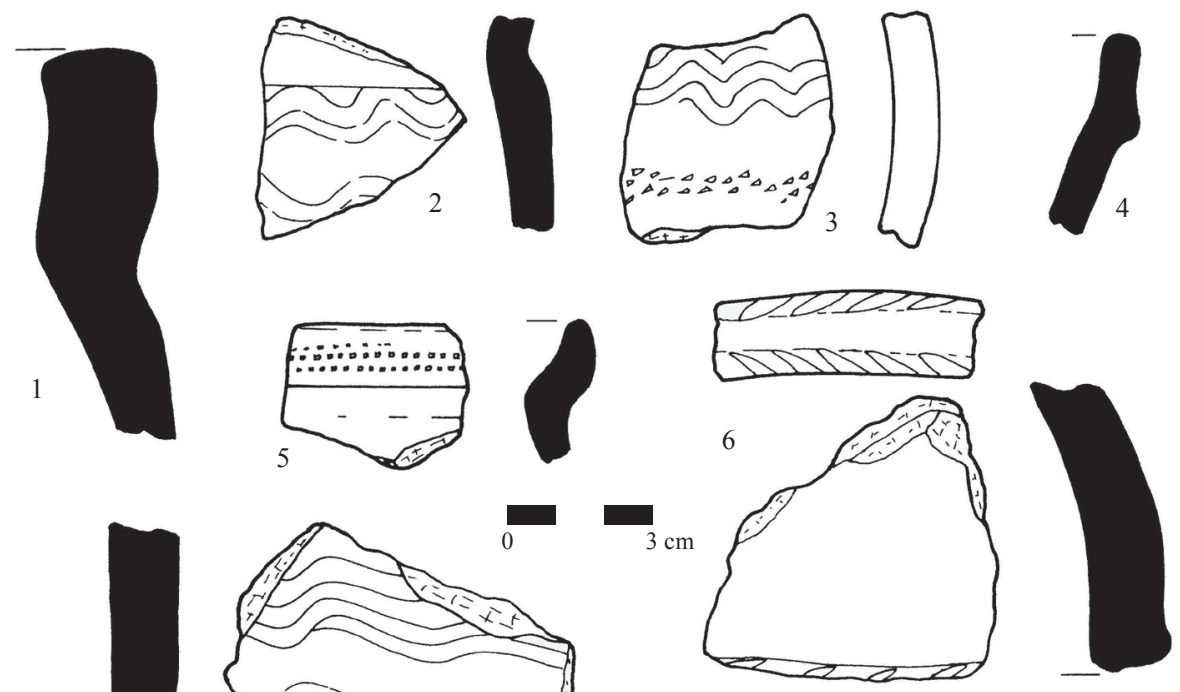

7
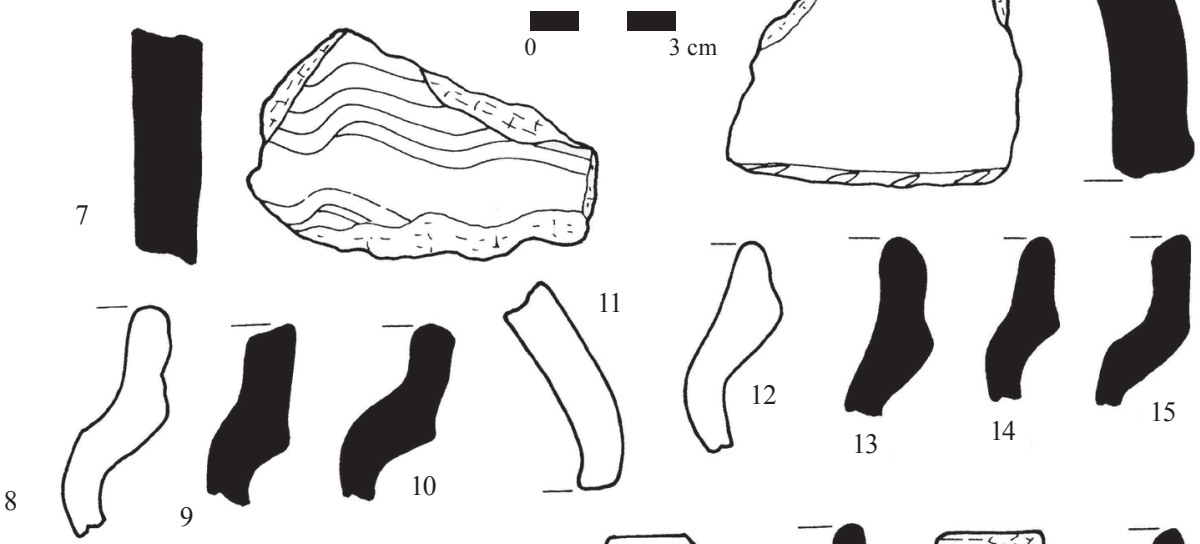

16
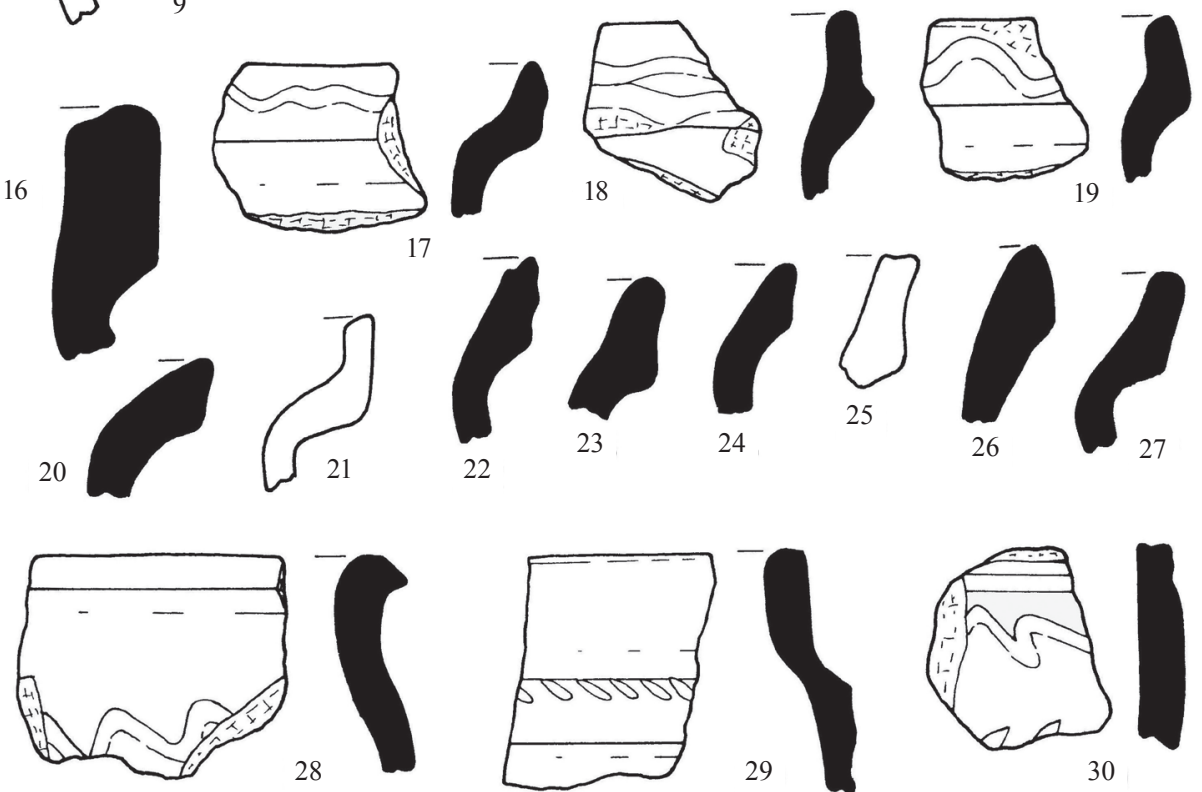

Obr. 1. 1-27 - Chornice 1a; 28-30 - Chornice 1b (výběr nálezů, vyplněný profil - grafitová keramika). Abb. 1. 1-27 - Chornice 1a; 28-30 - Chornice 1b (Fundauswahl, schwarzes Profil - Grafitkeramik). 
okraje (Chornice 1a, 1b, 5, obr. 1:10, 27; 2:23, 28; 4:1). Ojediněle se objeví okraj dovnitř skloněný (Chornice 1a, obr. 1:19) a s ohledem na výzdobu i okraj kalichovitý (Chornice 1a, obr. 1:5).

Nádobám s válcovitým hrdlem objevujícím se na Moravě na více lokalitách a reprezentovaným v zájmovém území zlomkem z lokality Chornice $1 \mathrm{~b}$ (obr. 1:29) byla v literatuře díky jejich vztahu k polskému prostředí věnována značná pozornost (Goš 1977, 268-299; Michna 1977, 223-224; Goš 1980, 162-169; Goš-Kapl 1986, 192, 194; Procházka-Štrof 1987; Staňa 1998, 275-276; Galuška 2009, 623-624; Procházka 2009, 172). Pomezí východních Čech a severozápadní Moravy je jedním z míst, kudy se tato keramika dostávala do východních Čech, popřípadě i dále (hradiště v Benátkách u Litomyšle a Cerekvice nad Loučnou, Charvát 1997, 16, obr. 7:9; 8:216; Hradec Králové, Richter-Vokolek 1995, 59, tab. 86:12; Chrudim, Frolík-Sigl 1998, 84, obr. 161; Předměřice nad Labem, Frolík-Sigl 1998a, 431; Libice nad Cidlinou, Princová-Justová 1994, 204, Abb. 6:1; Stará Boleslav, Boháčová 2003; k problematice souhrnně Bláha 2000). Ze severní části Boskovické brázdy známe zlomky nádob $\mathrm{s}$ válcovitým hrdlem ještě z Bořitova (Procházka-Štrof 1983, 51, obr. 5:1; 1987, 102-103, Ryc. 1d) a Hradiska u Svitávky (Procházka 1984, 434, obr. 1:11).

Do 11. století náleží i podle výzdoby provedené hřebenovým nástrojem kyjovitý při vnějším okraji vzhůru vytažený okraj zásobnice z lokality Chornice 5 (obr. 2:2), 12. století odpovídají kyjovité okraje zhruba obdélného průřezu z Chornice 1a (obr. 1:1, 16), Chornice 5 (obr. 2:1), kyjovitý okraj ze stejné lokality (obr. 2:5) již odpovídá 13. století (Goš-Karel 1979; Procházka-Peška 2007, 168, 220-221; Faltýnek-Novák-Šlézar 2018, 148).

Ve výzdobě se na keramice z Malé Hané setkáváme s doznívající hřebenovou vlnicí (obr. 1:2, $3,7 ; 2: 2,3,25)$ a vrypy provedenými vícehrotým nástrojem (obr. 2:2, 24), často ovšem již aplikovanými na grafitové hrnčině, jednotlivými vrypy sestavovanými do řad (obr. 1:29, 30; 2:1, 4, 29; $3: 3,11 ; 4: 2,6)$, ojediněle se objeví řady vrypů na ploše pod okrajem (obr. 3:26) a křŕžící se vrypy na podhrdlí (obr. 3:1). S vrypy se setkáváme i na okrajových ploškách (obr. 1:6; 4:5). Běžně se objevuje jednoduchá (obr. 1:17, 19, 28, 30;2:1, 11, 21, 28; 3:11, 22; 4:1, 5) nebo vícenásobná vlnice (obr. 1:18; 2:23; 3:12, 24). Se 13. stoletím se pojí výzdoba s pomocí rádélka (obr. 1:5; 2:26; 3:13, 27) doložená na nádobě z mincovního depotu v Křenově na Svitavsku datované díky mincím ještě do poslední čtvrtiny 13. století (Grossmannová-Vích 2014).

$\mathrm{K}$ esovité záušnici publikované již dříve z lokality Biskupice $4 \mathrm{c}$ a získané rovněž s pomocí detektoru kovů (Profantová-Vích 2008, 158, obr. 2:1) přibyly další dva exempláře, jeden celý a jeden s odlomenou částí s esovitou kličkou, obě záušnice pochází z lokality Chornice 1a (obr. 5:3-4). Esovité záušnice patří $\mathrm{k}$ charakteristické hmotné náplni mladší doby hradištní, přičemž mají postupnou tendenci se zvětšovat, ovšem jejich vypovídací hodnota naráží na řadu problémů (souhrnně Tomková 2005; Štefan 2010 s další literaturou). V Čechách máme jejich nástup prokázán v 10. století (Štefan 2010, 174, 176), analýza venkovských moravských pohřebišt' ukazuje, že na nich se esovité záušnice objevují až v prvních desetiletích 11. století (Ungerman 2010).

Do mladší doby hradištní se hlásí i tři olověná kolečka se středovým otvorem z lokalit Chornice 1a a Jevíčko-předměstí 3 (obr. 5:2, 16, 18). V typologickém tř́íění K. Wachowského (později dále rozpracovávaném, např. Tabaka 2005) se jedná o typ B (Wachowski 1974, 180-181). Funkce těchto předmětů zůstává stále nevyřešena, byly kladeny do souvislosti s rybolovem i považovány za kupecká závaží, stále zřetelněji se však jeví jejich souvislost s obchodem, protože se často nachází spolu s mincemi a bimetalickými závažími obvykle s vazbou na významná centra (Bodnar-Rozmus-Szmoniewski 2007, 26-28, 34-40; Rozmus 2016, 264-265 s další literaturou). Stále více je dnes zvažována možnost uživání olověných koleček se středovým otvorem jako nemincovního platidla (Wachowski 1974, 194; Bodnar-Rozmus-Szmoniewski 2007, 46-100). Zajímavé je, že možný vztah k mincovním nálezům platí i pro Malou Hanou, což dokládají mince z lokalit Chornice 1a, 5 (denár Vratislava II. typu Cach 334 a denár Oty III. Dětleba, VidemanVích 2015) a Jevíčko-předměstí 3 (imitativní denár konce 10. století, Videman 2017, 22; 2018, 218). V naší literatuře stojí olověné artefakty bohužel stále na okraji zájmu. Uváděny jsou z Dolních Věstonic - Vysoké zahrady (Měř́nský 1986, 62, obr. 28:2-4), Olomouce (Bém a kol. 2001, 137, 

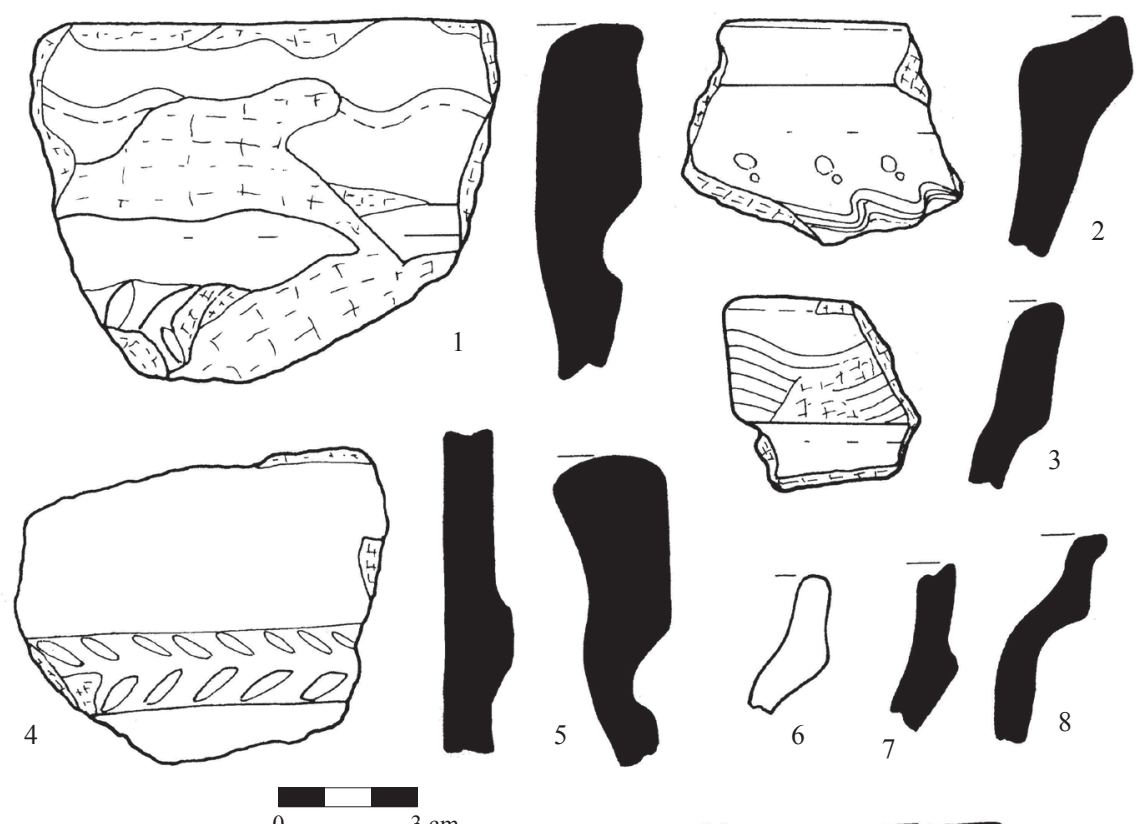

5
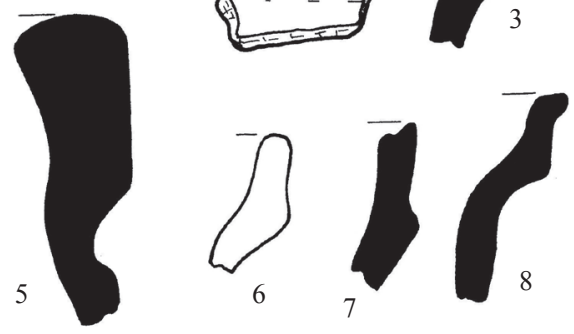

9
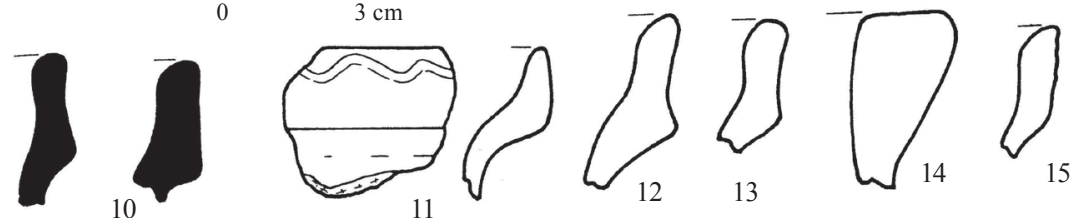

16

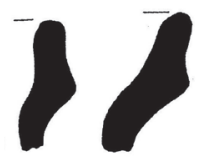

17

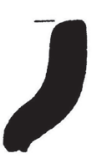

18

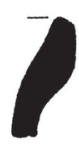

19

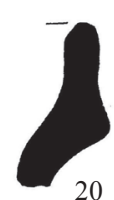

20
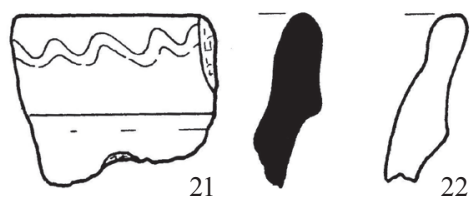
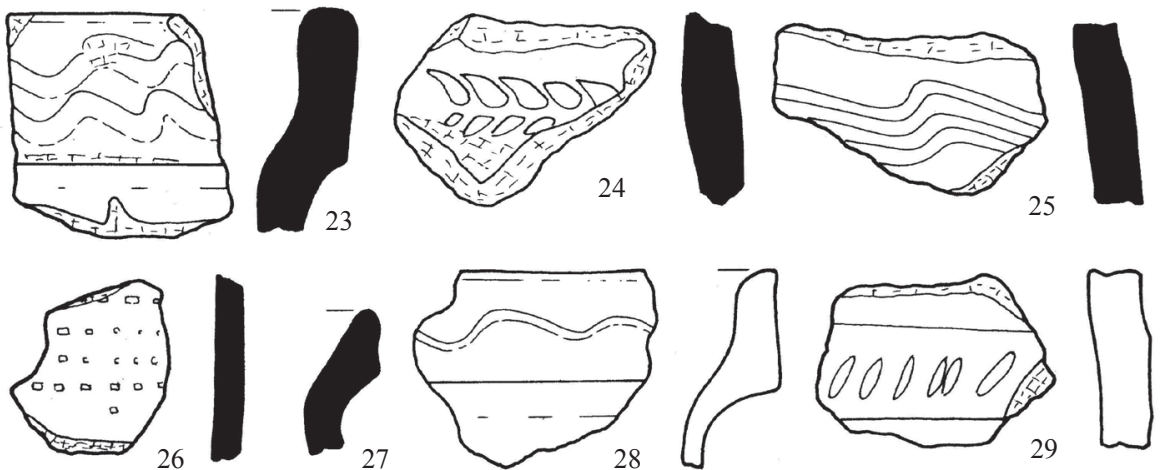

Obr. 2. 1-29 - Chornice 5 (výběr nálezů, vyplněný profil - grafitová keramika).

Abb. 2. 1-29 - Chornice 5 (Fundauswahl, schwarzes Profil - Grafitkeramik). 

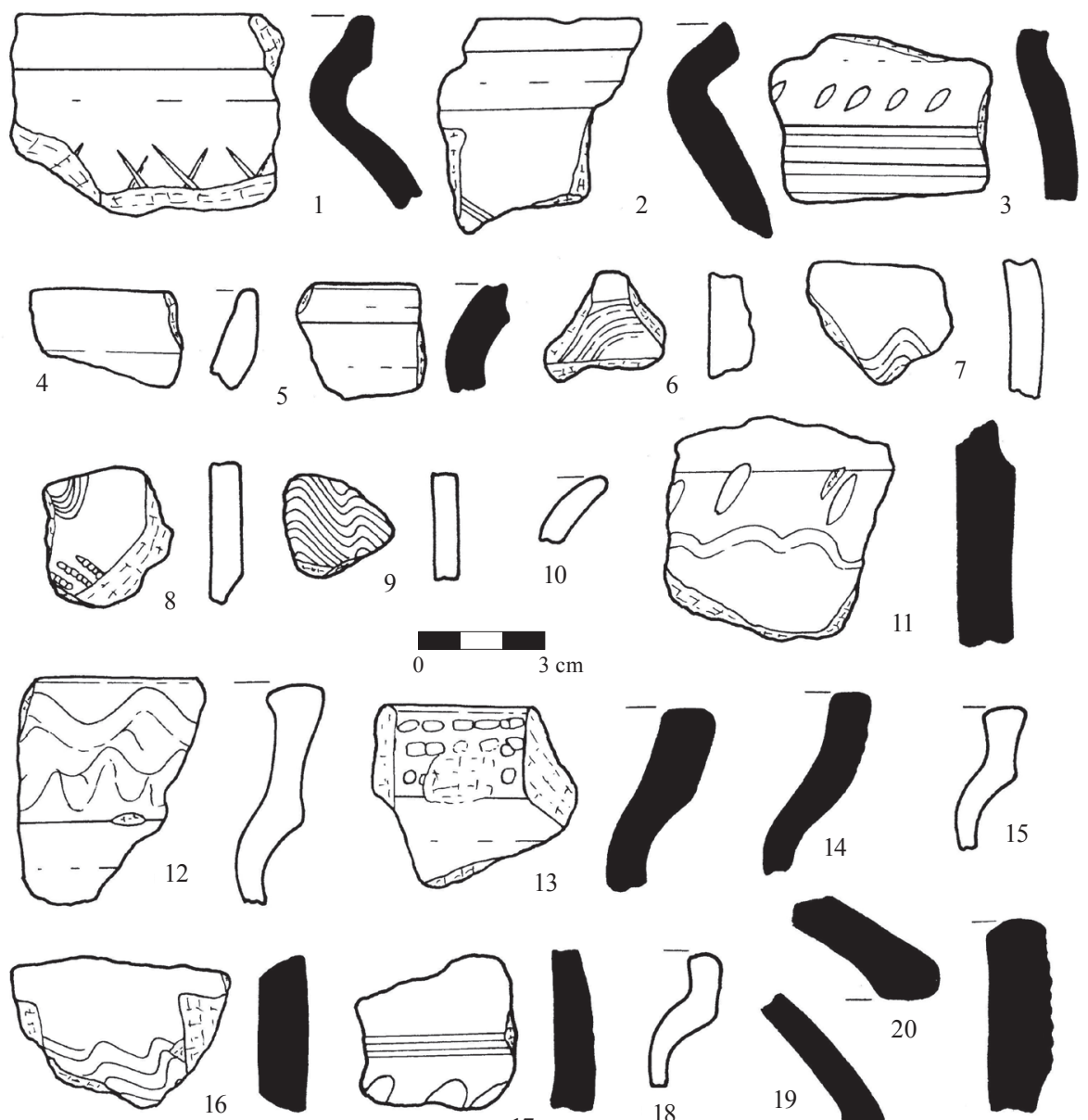

18
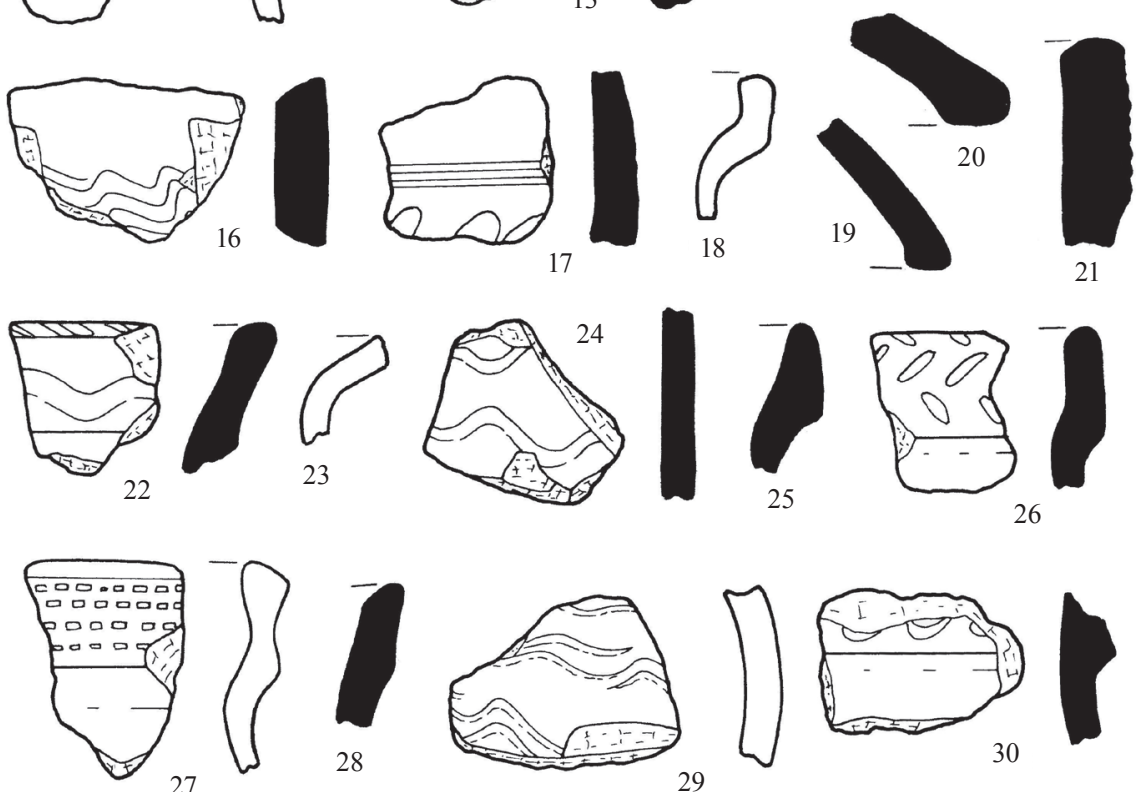

Obr. 3. 1-3 - Biskupice 4c; 4-11 - Drválovice 1 - Kambovo pole; 12-21 - Unerázka 2; 22-26 - Biskupice 3a; 27-28 - Biskupice 3b; 29 - Chornice 2c; 30 - Lázy 3c (vyplněný profil - grafitová keramika).

Abb. 3. 1-3 - Biskupice 4c; 4-11 - Drválovice 1 - Kambovo pole; 12-21 - Unerázka 2; 22-26 - Biskupice 3a; 27-28 - Biskupice 3b; 29 - Chornice 2c; 30 - Lázy 3c (schwarzes Profil - Grafitkeramik). 
obr. 171) a Žatce (Wieczorek-Hinz et al. 2000, 272). Větší soubory byly zevrubněji publikovány pouze z Roudnice na Královéhradecku (Bláha-Hejhal-Skala 2013) a zejména z Kostic na Břeclavsku (Macháček-Měchura 2013), přičemž jako zdroj olova pro Čechy a Moravu mohlo sloužit území Polska (Macháček-Měchura 2013, 280), což snad nově naznačují i izotopové analýzy (Ettler a kol. 2015).

V zájmovém území se poměrně často setkáváme s různými variantami přezek odlitých z bronzu s rámečkem ve tvaru D (Chornice 1a, obr. 5:1; Chornice 6a, obr. 5:10; Chornice 3c, obr. 5:14), popř́ípadě se zhruba oválným tvarem s rovnými stranami tam, kde je upevněn trn, a protilehlou týlovou stranou (Boršov, obr. 5:6; Městečko Trnávka 5, obr. 5:7; Chornice 6a, obr. 5:9). Týlová strana je obvykle vývalkovitě členěna. Tyto přezky mohou někdy být opatřeny plechovou různě zdobenou příchytnou destičkou (Wachowski 1994, 183), která se však v případě prezentovaných exemplářů nedochovala ani $\mathrm{v}$ jediném prŕpadě. $\mathrm{S}$ výskytem těchto přezek se počítá od 13. po starší úsek 14. století (Fingerlin 1971, 65-70; Ruttkay 1989, 364; Heindel 1990, 23-24; Krabath 2001, 145, 158) s následným dalším vývojem. To potvrzují i nálezy z českých
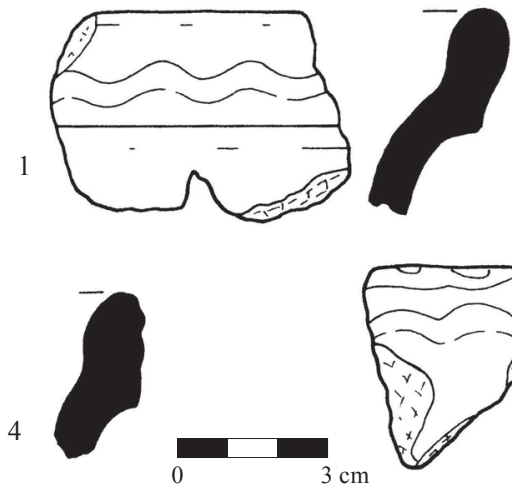
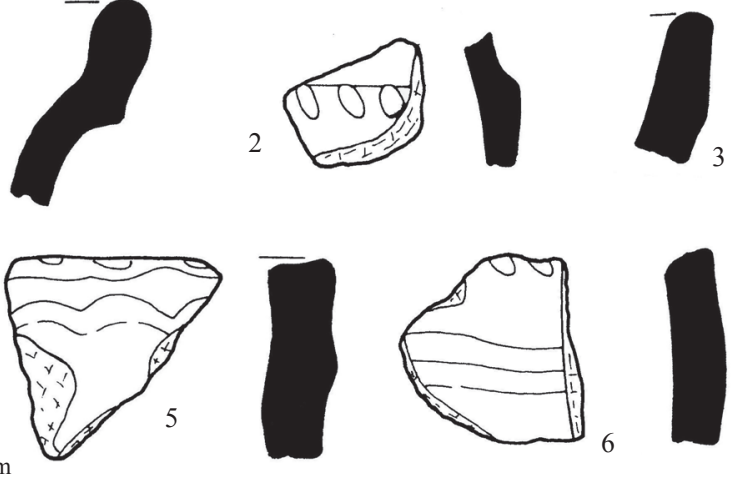

Obr. 4. 1-4 - Petrůvka 1; 5-6-Městečko Trnávka 8 (vyplněný profil - grafitová keramika).

Abb. 4. 1-4 - Petrůvka 1; 5-6-Městečko Trnávka 8 (schwarzes Profil - Grafitkeramik).

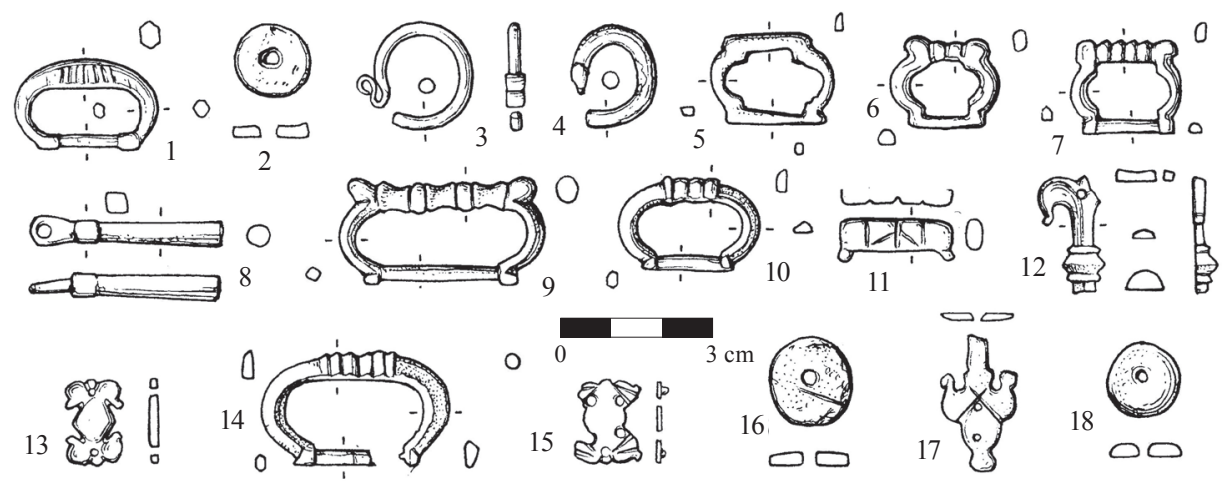

Obr. 5. Kovové artefakty. 1-4 - Chornice 1a; 5 - Rozstání 2; 6 - Boršov; 7 - Městečko Trnávka 5; 8 - Chornice 6b; 9 -13 Chornice 6a; 14 - Chornice 3c; 15 - Chornice 19; 16, 18 - Jevíčko-předměstí 3; 17 - Jevíčko-předměstí 28. Kresba M. Černý.

Abb. 5. Metallartefakte. 1-4-Chornice 1a; 5-Rozstání 2; 6-Boršov; 7-Městečko Trnávka 5; 8-Chornice 6b; 9-13-Chornice 6a; 14 - Chornice 3c; 15 - Chornice 19; 16, 18 - Jevíčko-předměstí 3; 17 - Jevíčkoo-předměstí 28. Zeichnungen M. Černý. 

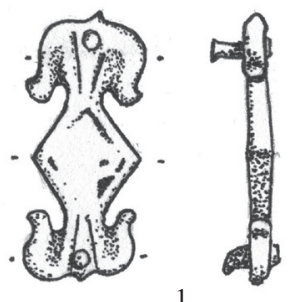
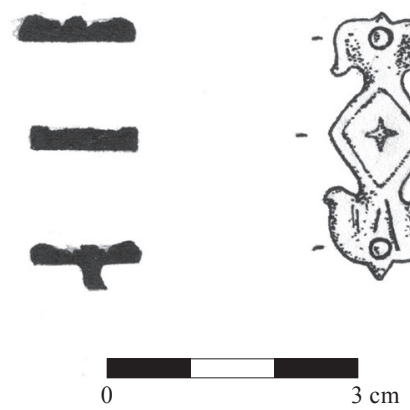
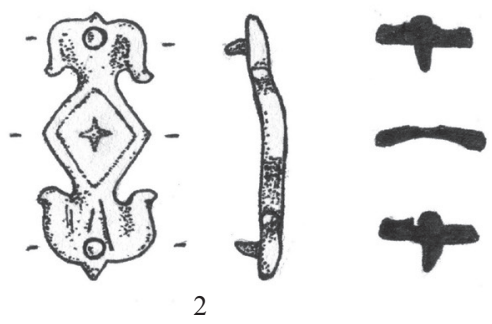

Obr. 6. 1-2 - Březová nad Svitavou. Liliovitá opasková kování. Kresba M. Pechancová.

Abb. 6. 1-2 - Březová nad Svitavou. Lilienförmige Gürtelbeschläge. Zeichnungen K. Pechancová.

zemí. Do 13. století jsou archeologicky datovány přezky z Hradišt'ka u Davle (Richter 1982, 188, obr. 132:2-6, 8-9), Jihlavy (Macháňová 2007, 271-272; 2009, 161-164, obr. 1), hradu Tachova (Durdík 2004, tab. VIII:5; 2007, 140-141), Černova - Cvilínku (Hrubý-Hejhal 2011, obr. 53:6-7), Vyskytné nad Jihlavou (Zimola-Vokáč 2011, 432, 434, obr. 6) a torzo opasku opatřené touto přezkou pochází z Veselí nad Moravou (Žákovský-Hošek 2015, 237, obr. 17f). Další nálezy jsou nestratifikovány, popřípadě byly druhotně přemístěny, jako například přezka ze zaniklé Bystřece (Belcredi 1997, 117, obr. 8b; 2006, 374, tab. XLII 4) či z Mostu (Klápště 1983, 462-463, obr. 7:6, přehled nálezů včetně nestratifikovaných Šlancarová 2018, 168-170). K těmto přezkám se hlásí i méně často se vyskytující exempláře nezdobené reprezentované v zájmovém území př̀ezkou z Rozstání (obr. 5:5) a zlomkem přezky z Chornice 6a s týlem opatřeným rytím (obr. 5:11). Podobné známe například ze Sezimova Ústí (Hrdlička-Richter-Smetánka 1966, 678, obr. 208) či hradu Orlík u Brandýsa nad Orlicí (Vích-Žákovský 2016, obr. 35:49; 39:49).

Specifickými artefakty souvisejícími s oděvem jsou drobná kování liliovitého tvaru, v zájmovém území doložená z lokalit Chornice 6a (obr. 5:12-13), Chornice 19 (obr. 5:15) a Jevíčko-předměstí 28 (obr. 5:17). Nošena byla na opascích ve 13. a na počátku 14. století (Fingerlin 1971, 80, 85; Ruttkay 1989, 367). Na našem území mají analogie v nálezech z Hradiště u Sekanky (Richter 1982, 187, obr. 132:15, 16) a Jihlavy (Macháňová 2007, 272, obr. 2:19; 2009, 167, obr. 3) a vzdálenější analogii z Olomouce (Šlancarová-Křížová 2009, 155, obr. 10). Dva nepublikované nálezy nalezené s pomocí detektoru kovů pochází od Březové nad Svitavou na nedalekém Svitavsku $^{5}$ (obr. 6).

Poněkud překvapivě se $\mathrm{v}$ nálezovém souboru setkáváme se zlomkem ramene skládacích vážek registrovaným na lokalitě Chornice 6a (obr. 5:8). Zjištěný exemplář dobře koresponduje s postupně se rozšiřující pramennou základnou (Richter 1963; Michna 1979; Ježek 2002; Doležel 2007a). Vzhledem $\mathrm{k}$ vazbě na dálkový obchod a na oblasti hornických revírů (a tudíž výskyt zejména v městském prostředí, Ježek 2002, 453-454; Doležel 2007a, 147-148) je přítomnost tohoto typu předmětů u Chornice jistým překvapením. Výskyt vážek se časově váže $\mathrm{k} 13$. století, od první poloviny 14. století četnost jejich výskytu zřejmě se změnou ražené mince zřetelně klesá (Doležel 2007a, 154). Typologické určení skládacích vážek je vzhledem ke stavu dochování nemožné, vzhledem ke krychličkovitému zesílení konce ramene jde pravděpodobně o typ 8 (Steuer 1997, 29, 32-33, 172, Abb. 10, 117), a to i s ohledem na skutečnost, že naprostá většina českých a moravských vážek náleží právě tomuto typu (Doležel 2007a, 148), vyloučit ale s jistotou nemůžeme ani jinou typologickou př́islušnost.

5 Artefakty nalezla v poloze Vysoké stráně ve svahu při jižním okraji intravilánu s pomocí detektorů kovů Monika Beránková v letech 2016 a 2018. Předměty se nacházely v moderní lesní cestě zaříznuté do svahu a jejím bezprostředním okolí, UTM souřadnice jsou E 0610187 , N 5498978. 
Tab. 1. Přehled údajů o kovových artefaktech. ${ }^{6}$

\begin{tabular}{|c|c|c|c|c|c|c|c|}
\hline Lokalita & Typ artefaktu & Materiál & $\begin{array}{l}\text { Evidenční } \\
\text { číslo }\end{array}$ & $\begin{array}{c}\mathrm{E} \\
(\mathrm{UTM})\end{array}$ & $\begin{array}{c}\mathrm{N} \\
(\mathrm{UTM})\end{array}$ & $\begin{array}{l}\text { Rozměry } \\
(\mathrm{mm})\end{array}$ & $\begin{array}{c}\text { Hmotnost } \\
\text { (g) }\end{array}$ \\
\hline Boršov & rámeček přezky & bronz & 3 & 0615084 & 5511465 & $22 \times 18 \times 3$ & 3,50 \\
\hline Chornice 1a & $\begin{array}{l}\text { celá esovitá } \\
\text { záušnice }\end{array}$ & bronz & 75 & 0623530 & 5503074 & $22 \times 23 \times 4$ & 2,87 \\
\hline Chornice la & torzo záušnice & bronz & 74 & 0623496 & 5503111 & $21 \times 18 \times 4$ & 3,55 \\
\hline Chornice 1a & $\begin{array}{c}\text { kolečko se } \\
\text { středovým otvorem }\end{array}$ & olovo & 60 & 0623544 & 5503091 & $15,5 \times 15 \times 3$ & 4,30 \\
\hline Chornice 1a & rámeček přezky & bronz & 21 & 0623581 & 5503058 & $29 \times 18 \times 5$ & 5,48 \\
\hline Chornice $3 c$ & $\begin{array}{l}\text { poškozený rámeček } \\
\text { přezky }\end{array}$ & bronz & 7 & 0624419 & 5503714 & $38 \times 23 \times 3$ & 5,50 \\
\hline Chornice $6 a$ & rámeček přezky & bronz & 32 & 0625716 & 5502402 & $42 \times 22 \times 5$ & 8,37 \\
\hline Chornice $6 a$ & rámeček přezky & bronz & 31 & 0625863 & 5502418 & $29 \times 19 \times 3$ & 3,38 \\
\hline Chornice 6a & $\begin{array}{l}\text { zlomek rámečku } \\
\text { přezky }\end{array}$ & bronz & 18 & 0625828 & 5502369 & $24 \times 9 \times 4$ & 3,58 \\
\hline Chornice $6 a$ & liliovité kování & bronz & 22 & 0625820 & 5502364 & $18 \times 12 \times 2$ & 1,52 \\
\hline Chornice $6 \mathrm{a}$ & $\begin{array}{l}\text { část liliovitého } \\
\text { kování }\end{array}$ & bronz & 40 & 0625739 & 5502283 & $24 \times 12 \times 4$ & 2,68 \\
\hline Chornice $6 \mathrm{~b}$ & $\begin{array}{l}\text { zlomek ramene } \\
\text { skládacích vážek }\end{array}$ & bronz & 7 & 0625866 & 5502470 & $39 \times 6 \times 5$ & 4,48 \\
\hline Chornice 19 & liliovité kování & bronz & 103 & 0626928 & 5504177 & $17 \times 13 \times 3$ & 1,14 \\
\hline $\begin{array}{l}\text { Jevíčko- } \\
\text {-předměstí } 3\end{array}$ & $\begin{array}{c}\text { kolečko se } \\
\text { středovým otvorem }\end{array}$ & olovo & 83 & 0624062 & 5498835 & $\begin{array}{c}15,5 \times 15 \times \\
3,5\end{array}$ & 4,97 \\
\hline $\begin{array}{l}\text { Jevíčko- } \\
\text {-předměstí } 3\end{array}$ & $\begin{array}{c}\text { kolečko se } \\
\text { středovým otvorem }\end{array}$ & olovo & 105 & 0624247 & 5498808 & $18 \times 17 \times 3$ & 6,11 \\
\hline $\begin{array}{l}\text { Jevíčko- } \\
\text {-předměstí } 28\end{array}$ & $\begin{array}{l}\text { část liliovitého } \\
\text { kování }\end{array}$ & bronz & 36 & 0623095 & 5499554 & $28 \times 16 \times 1,5$ & 2,12 \\
\hline $\begin{array}{l}\text { Městečko } \\
\text { Trnávka } 5\end{array}$ & rámeček přezky & bronz & 13 & - & - & $22,5 \times 19 \times 3$ & 3,51 \\
\hline Rozstání 2 & rámeček přezky & bronz & 17 & 0624468 & 5509672 & $25 \times 19 \times 1,5$ & 2,42 \\
\hline
\end{tabular}

Jediným zástupcem skleněných artefaktů sledovaného období v zájmovém území je podélně členěný korálek elipsoidního tvaru vyrobený z modrého neprůsvitného skla (délka 13,8 mm, maximální šířka 7,5 mm, hmotnost $0,81 \mathrm{~g}$, obr. 7) nalezený autorem při povrchovém sběru 25. března 2011 na lokalitě Biskupice $4 c{ }^{7}$ Korálek lze formálně přiřadit k tzv. olivovitým perlám (k terminologii Krumphanzlová 1965, 168; Staššíková-Štukovská-Ungerman 2009, 138; Košta-Tomková 2011, 307-308 s další literaturou). Zároveň se však od nich zřetelně odlišuje, a to zejména krajně neobvyklým počtem deseti žeber, přičemž známé exempláře jich mají maximálně pět. Otázkou je, zda byl korál vyroben technikou pro tento typ artefaktu charakteristickou, totiž navíjením skla na trubičku z barevného kovu. Vzhledem k tomu, že je korál zhotoven z neprůsvitného skla, nemůže být př́ípadná kovová trubička vizuálně zjištěna, o přítomnosti či nepřítomnosti

6 Materiál zde byl určen jako bronz pouze na základě makroskopického určení, přesnější představu o složení slitiny by přinesla pouze příslušná analýza složení kovu. Evidenční číslo je číslo z evidence autora, kdy každé lokalitě je přiřazena samostatná číselná řada, čísla jsou přiřazována chronologicky podle data nálezu bez rozlišování jednotlivých období. Nezaměřený artefakt byl objeven spolupracovníkem Regionálního muzea, který v době nálezu nedisponoval ruční stanicí GPS.

7 Zaměřeno ruční stanicí GPS ve formátu UTM, E 0625818 , N 5501250. 
tohoto specifického technologického prvku tedy není možné s jistotou rozhodnout. ${ }^{8}$ Absenci kovové vložky u některých moravských exemplářů explicitně uvádí Č. Staňa $(1995$, 39-40). Olivovité perly jsou datovány do 9.-10. století, v Čechách snad s možným přežíváním do 11. století (Košta-Tomková 2011, 329-334).

Nálezy, i když získané povrchovým sběrem, tak dovolují alespoň ve velmi hrubých rysech nastínit vývoj v mladším úseku raného středověku v daném regionu.

Do povelkomoravského období až staršího úseku mladši doby hradištní náleží již dřive publikované lokality Chornice 16a, 16b (seříznuté či oble ukončené ven vyhnuté

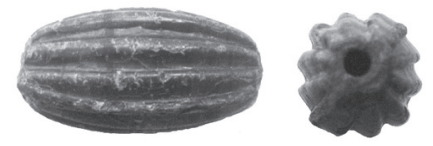

0

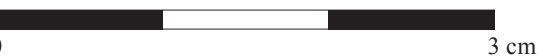

Obr. 7. Korálek z lokality Biskupice 4c.

Abb. 7. Perle von der Fundstelle Biskupice 4c. grafitové okraje a plastické lišty provedené na keramice v grafitovém materiálu, Profantová-

Vích 2008, obr. 12:1, 10,15), Jevíčko-předměstí 3 (seříznuté či oble ukončené ven vyhnuté okraje a plastické lišty, hřebenová vlnice, opět na střepu s výraznou příměsí grafitu, Profantová-Vích 2008, obr. 19:5; 23:19, olověná kolečka, imitativní denár), Cetkovice 3 (plastická lišta na keramice bez př́tomnosti grafitu, Profantová-Vích 2008, obr. 4:5), Cetkovice 1 (ven vyhnutý okraj v grafitovém provedení, Profantová-Vích 2008, obr. 3:2) a vzhledem k přítomnosti grafitové keramiky patrně i lokalita Chornice 11. Do tohoto období budou podle výskytu archaické hřebenové výzdoby na grafitovém materiálu (obr. 3:2) náležet i lokality Drválovice 1 - Kambovo pole a Biskupice 4c, otázkou zůstává, zda již v této době začíná osídlení i v lokalitě Chornice 1a (obr. 1:3). Zajímavé je, že s výjimkou lokalit Chornice 1a a Biskupice 4c uvedené lokality podle získaných nálezů zanikají a osídlení zde končí.

Se vzhůru vytaženými okraji příznačnými pro druhou polovinu 11. století a v protažené podobě pro 12. století se setkáváme především na lokalitě Chornice 1a, 1b, 5. Do 11. a 12. století se zde rovněž hlásí některé zásobnice s kyjovitým okrajem. Uvedené datování potvrzují vedle esovitých záušnic, olověného kolečka se středovým otvorem i mincovní nálezy - denár Vratislava II. a denár Oty III. Dětleba. Nízký vytažený okraj ukazuje na přežívání osídlení do druhé poloviny 11. století i na lokalitě Biskupice 4c. ${ }^{9}$

Nálezy římsovitých okrajů dokládají osídlení na lokalitě Chornice $1 \mathrm{a}, 1 \mathrm{~b}, 5$ ještě ve 13 . století, podle římsovitých okrajů s vnitřním prožlabením kombinovaným se seříznutím okraje dovnitř (srov. Faltýnek-Novák-Šlézar 2018, 148) zde osídlení vyznívá spíše až ve druhé polovině tohoto věku. Do 12.-13. století náleží i nečetná keramika z lokality Městečko Trnávka 8, kde na existenci sídliště ukazují i pozorované půdní příznaky. S keramikou 13. století se setkáváme i jinde (Biskupice 3a, 3b, Chornice 2c - Lázy 3c, Petrůvka, Staré Město u Moravské Třebové 8, Unerázka 2 - zde je ř́msovitý okraj kombinován s rádélkovou výzdobou), není ale vždy jednoduché rozhodnout, zda se jedná o indicii př́itomnosti intaktních archeologických situací v místě nálezu, či zda jde o druhotně zavlečenou keramiku. Druhou možnost může i nemusí dokládat pokročilá keramika 14. století (obr. 3:12, 3:27). Řada archeologických situací 13. století se naopak ukrývá pod zástavbou dnešních obcí. Keramika 13. století je někdy doprovázena kovovými předměty (Chornice 1a, Chornice $6 \mathrm{a}, 6 \mathrm{~b}$ ), s těmi se pak setkáváme i v podobě ojedinělých nálezů.

\footnotetext{
8 Přítomnost kovu nezaznamenal ani detektor kovů značky XP Deus nastavený na maximální citlivost, to může však být důsledek kombinace miniaturních rozměrů kovového jádra a koroze.

9 Tato velmi zajímavá lokalita poskytla bohužel jen nevelký počet keramických nálezů, oproti dřivějším předpokladům zde osídlení začíná snad již v době Velké Moravy. V nedávné době byla bohužel bez výzkumu zničena okrajová část lokality stavbou menší vodní nádrže.
} 


\section{Archeologické lokality}

Když pomineme řadu lokalit s raně středověkými nálezy, které ale není možné na základě nevýrazného materiálu blíže datovat (viz Profantová-Vích 2008), a hradiště (Biskupice - Nectava, Doležel 2007; Šlézar 2014; Knínice, návrší kolem kostela sv. Marka, Ferulík 1950; mařínské hradiště, Novotný 1971; Profantová-Vích 2008), setkáváme se v zájmovém území s raně středověkými lokalitami s různou délkou osídlení. Mladší doby hradištní se již nedočkaly tři lokality: Knínice 6 (keramika pražského typu s možným přežíváním do starší doby hradištní); Cetkovice 2, 5 (střední doba hradištní) a Vážany - Štěrchy (střední doba hradištní). Osm lokalit se starším základem se mladší doby hradištní dožívá. Jedná se o lokality Biskupice 4c; Cetkovice 1; Cetkovice 3; Drvalovice 1 - Kambovo pole; Chornice 6a, 6b; Chornice 11; Chornice 16a, 16b, 16c; Jevíčko-prredměstí 3; předpokládat se to dá u dalších (Chornice 23a, 23b), které však poskytly jen málo keramického materiálu. V mladší době hradištní bez vazby na starší substrát vzniká podle výpovědi povrchových sběrů zejména nálezově velmi výrazná lokalita Chornice 1a, $1 \mathrm{~b}, 5$ dožívající se 13 . století, kdy definitivně zaniká. Výhradně do 13. století (nezřídka s dalším pokračováním) se hlásí zlomky keramiky z lokalit Chornice 2c Lázy 3c, Městečka Trnávky 8 , Unerázky 2, s výhradami z Biskupic 3a, 3b (ojedinělý ven vyhnutý okraj) a z území severně od Malé Hané z lokalit Petrůvka 1 a Staré Město u Moravské Třebové 8. K těmto informacím je ovšem třeba přistupovat velmi opatrně, protože jsou založené na povrchových sběrech a o povaze intaktních archeologických situací v daných lokalitách nevíme vůbec nic. I když jsme se snažili situace s druhotně zavlečenou keramikou nebrat v potaz, u keramických zlomků ze 13. století je mnohdy obtížné rozlišit, zda sebrané střepy indikují přítomnost intaktních archeologických situací v místě nálezu, nebo jde pouze o keramiku sekundárně zavlečenou z areálů dnešních vsí majících svůj počátek ve 13. století nebo i dříve.

\section{Závěr}

Prezentované prameny k mladšímu úseku raného středověku severní části Boskovické brázdy mají sice omezenou vypovídací hodnotu, přesto ale přinášejí některá zajímavá zjištění.

Přítomnost člověka na Malé Hané a zejména v její severní části máme pro mladší úsek raného středověku doloženu na základě výpovědi archeologických pramenů v 10. či první polovině 11. století s návazností na starší substrát. Objeví se ovšem i sídliště vznikající v mladší době hradištní bez předchozího vývoje (když ponecháme stranou osídlení pravěké) a v průběhu 13. století opět mizící. Jedná se zejména o sídliště Chornice $1 \mathrm{a}, 1 \mathrm{~b}, 5$ vynikající nejen množstvím zjištěné keramiky, ale i přítomností kovových artefaktů a raně stř̌edověkých mincí. I když jsou prezentované informace o kontinuitě/diskontinuitě osídlení postavené výhradně na pramenech vytržených zemědělskou činností ze svého původního kontextu, a nelze proto prozatím z tohoto zjištění vyvozovat žádné dalekosáhlé závěry, zaznamenáváme podle dosavadního stavu poznatků v osídlení přece jen určitý předěl někdy v 10. až první polovině 11 . století, kdy na většině lokalit osídlení končí, popřípadě nejsme schopni jeho pokračování archeologicky postihnout.

Rozsah osídlení v mladším úseku raného středověku kopíruje starší situaci ze střední doby hradištní, kdy se osídlení severním směrem zastavilo na dnešní severní hranici k. ú. Chornice (obr. 8). K plošnému zasídlení zájmového území a patrně i jisté stabilizaci sídelní sítě tedy dochází již v období Velké Moravy. Území ležící severně od Malé Hané byla na základě aktuálního stavu poznání archeologických pramenů a navzdory lokální př́itomnosti úrodných půd využívaných člověkem již v pravěku (především okolí Starého Města u Moravské Třebové) kolonizována až v průběhu 13. století (obr. 9), což platí i pro nedaleké Svitavsko (nález liliovitých opaskových kování z Březové nad Svitavou). Mladší doba hradištní se alespoň co do rozlohy obsazeného území tedy z tohoto hlediska jeví jako obdobím určité stagnace. Vyloučit sice nemůžeme ostrůvkovitý průnik kolonistů na neosídlená území již v 11. či spíše ve 12. století, stávající doklady jsou však pro to zatím více než jen ojedinělé (např. Dětřichov, Bolina-Němcová-Šlézar 2008, obr. 1 A 2194) a navíc postrádají spolehlivé nálezové okolnosti, popřípadě nemůžeme vyloučit riziko pomíchání 


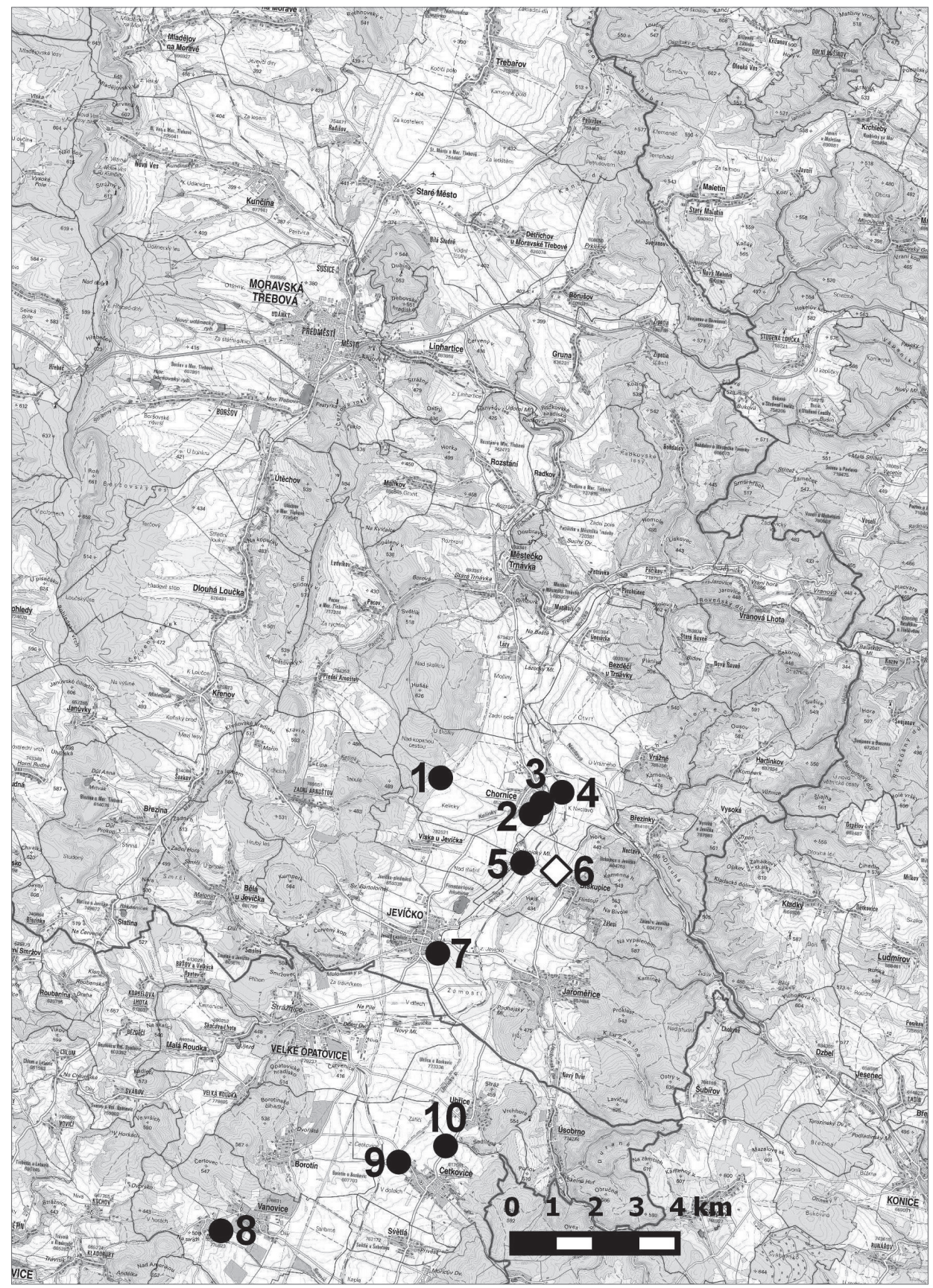

Obr. 8. Malá Haná. Prostorová distribuce nálezů mladší doby hradištní. 1 - Chornice 1a, 1b, 5; 2 - Chornice 6a, 6b; 3 - Chornice 16a, 16b; 4 - Chornice 11; 5 - Biskupice 4c; 6 - Biskupice 3a, 3b; 7 - Jevíčko-předměstí 3; 8 - Drválovice 1 - Kambovo pole; 9 - Cetkovice 1; 10 - Cetkovice 3. Kolečko - sídliště, kosočtverec - ojedinělý nález, prázdný symbol - nejisté, plný symbol-jisté.

Abb. 8. Malá Haná. Räumliche Verteilung der Funde aus der Jungburgwallzeit. 1 - Chornice 1a, 1b, 5; 2 - Chornice 6a, 6b; 3 - Chornice 16a, 16b; 4 - Chornice 11; 5 - Biskupice 4c; 6 - Biskupice 3a, 3b; 7 - Jevíčko-předměstí 3; 8 - Drválovice 1 - Kambovo pole; 9 - Cetkovice 1; 10 - Cetkovice 3. Punkte - Siedlungen, Quadrat - Einzelfund, weißes Symbol - unsicher, schwarzes Symbol - sicher. 


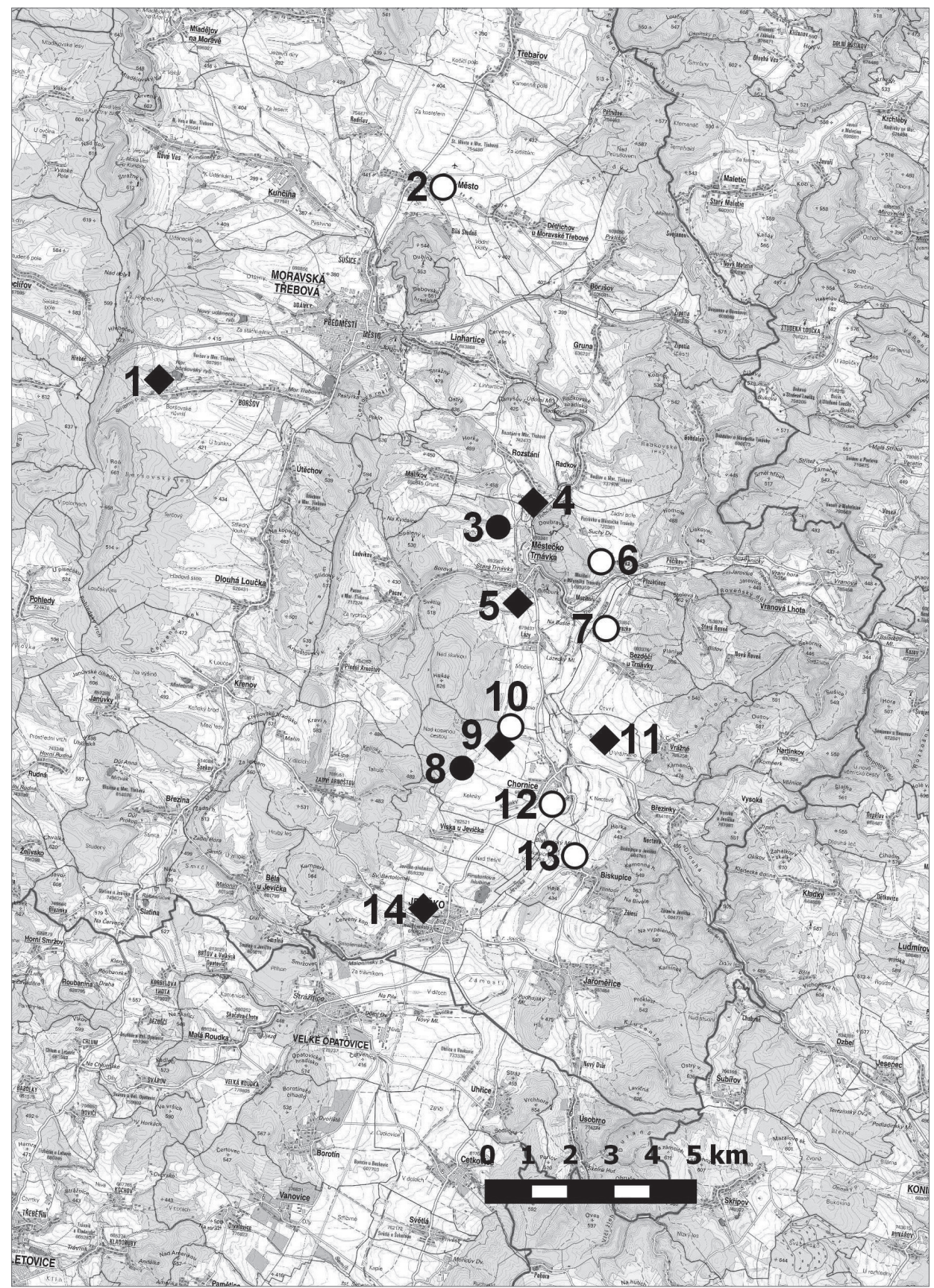

Obr. 9. Malá Haná. Prostorová distribuce nálezů tř̌ináctého století. 1 - Boršov; 2 - Staré Město u Moravské Třebové 8; 3 - Městečko Trnávka 8; 4 - Rozstání 2; 5 - Městečko Trnávka 5; 6 - Petrůvka 1; 7 - Unerázka 2; 8 - Chornice 1a, 1b, 5; 9 - Chornice 3c; 10 - Chornice 2c - Lázy 3c; 11 - Chornice 19; 12 - Chornice 6a, 6b; 13 - Biskupice 3a, 2b; 14 - Jevíčko-předměstí 28 . Kolečko - sídliště, kosočtverec - ojedinělý nález, prázdný symbol - nejisté, plný symbol - jisté.

Abb. 9. Malá Haná. Räumliche Verteilung der Funde aus dem 13. Jahrhundert. 1 - Boršov; 2 - Staré Město u Moravské Třebové 8; 3 - Městečko Trnávka 8; 4 - Rozstání 2; 5 - Městečko Trnávka 5; 6 - Petrůvka 1; 7 - Unerázka 2; 8 -Chornice 1a, 1b, 5; 9 - Chornice 3c; 10 - Chornice 2c - Lázy 3c; 11 - Chornice 19; 12 - Chornice 6a, 6b; 13 - Biskupice 3a, 2b; 14 - Jevíčko-předměstí 28. Punkte - Siedlungen, Quadrat - Einzelfund, weißes Symbol - unsicher, schwarzes Symbol - sicher. 
starých nálezů v muzejních sbírkách, které měly někdy dosti pohnuté osudy. V otázce př́ípadného rozšiřování osídleného území severním směrem v mladší době hradištní nezbývá než vyčkat dalších výzkumů.

Nové nálezy kovových předmětů představují běžnou dobovou hmotnou kulturu, pouze mince, byt' se zatím vyskytují sporadicky (vedle výše uvedených zmiňme i nedávno publikovaný izolovaný společný nález denáru Spytihněva II. a saského kř́ižového denáru Jindřicha III. či Jindřicha IV. z lesa v blízkosti Jevíčka, Videman-Vích 2020), dokládají dostupnost raženého kovu. Překvapivá a zatím jen obtížně vysvětlitelná zůstává přítomnost dokladu obchodní činnosti v podobě zlomku skládacích vážek z Chornic ve venkovském prostředí. Otázkou a úkolem dalšího výzkumu zatím je, zda s obchodem souvisí nálezy olověných koleček se středovým otvorem.

\section{Prameny a literatura}

BALCÁRKOVÁ, A., 2013: Povelkomoravská a mladohradištní keramika datovaná mincemi z Kostic - Zadního hrúdu, AR LXV, 786-824.

BELCREDI, L., 1997: Zaniklá ves Bystřec - usedlost číslo X. In: Z pravěku do středověku. Sborník k 70. narozeninám Vladimíra Nekudy, 108-122. Brno.

- 2006: Bystřec. O založení, životě a zániku středověké vsi. Archeologický výzkum vsi Bystř̌ece 1975-2005. Brno.

BÉM, M. a kol., 2001: Archeologické zrcadlení - Archaeological reflections. Olomouc.

BISTŘICKÝ, J., 1993: Zakládací listina kláštera Hradiska u Olomouce a počátky české panovnické listiny, VVM XLV, 131-136.

- 1998: Zdíkovy listiny, ČČH 96, 292-306.

BLÁHA, R., 2000: Doklady nádob s válcovitým hrdlem v Čechách a jejich chronologie. Nepublikovaná seminární práce, ulož. na ÚAM FF MU, Brno.

BLÁHA, R.-HEJHAL, P.-SKALA, J., 2013: Raně středověké olověné artefakty z katastru Roudnice (okr. Hradec Králové). In: Argenti fossores et alii. Znaczenie gospodarcze wschodnich części Górnego Śląska i zachodnich krańców Małopolski w późnej fazie wczesnego średniowiecza (X-XIII wiek) (Boroń, P., ed.), 289-305. Wrocław.

BOHÁČOVÁ, I., 2003: Doklady česko-polských kontaktů z raně středověké Staré Boleslavi - Belege der tschechisch-polnischen Kontakte im Frühmittelalter in Stará Boleslav (Alt Bunzlau), AH 28, 47-53.

BODNAR, R.-ROZMUS, D.-SZMONIEWSKI, B. Sz., 2007: Wczesnośredniowieczne odważniki i ciężarki ołowiane z Dąbrowy Górniczej - Łośnia - Early mediaeval commercial weights and lead weights from Dąbrowa Górnicza - Łosień. Dąbrowa Górnicza - Kraków.

BOLINA, P., 1999: K interpretaci a datování Zdíkových listin, ČČH 97, 273-292.

- 2003: Kde byl přepaden biskup Jindřich Zdík roku 1145 (Příspěvek k historii moravsko-českého pomezí), ČMM CXXII, 343-373.

BOLINA, P.-NĚMCOVÁ, J.-ŠLÉZAR, P., 2008: K počátkům hradů na Moravskotřebovsku, CB 11, 53-88.

CDB I: Codex Diplomaticus et Epistolaris regni Bohemiae (Friedrich, G., ed.). Pragae 1904-1907.

CDB IV/1: Codex Diplomaticus et Epistolaris regni Bohemiae (Šebánek, J.-Dušková, S., edd.). Pragae 1962. CDB V/2: Codex diplomaticus et epistolaris regni Bohemiae. (Šebánek, J.-Dušková, S., edd.). Pragae 1981.

CIB I: Codex juris Bohemici. Tomus primus, aetatem Přemyslidarum continens. Pragae 1867.

ČECHOVÁ, G., 1978: Úsobrnská celnice. Př́íspěvek k historii Trstenické stezky. In: In memoriam Zdeňka Fialy - Z pomocných věd historických, 25-40. Praha.

DOLEŽEL, J., 2003: K etnické struktuře středověké kolonizace Drahanské vrchoviny - Zur ethnischen Struktur der mittelalterlichen Kolonisation des Hochlandes Drahanská vrchovina, AH 28, 123-173.

- 2007: Biskupice (k. ú. Biskupice u Jevíčka, okr. Svitavy), PV 48, 405-410.

- 2007a: Na okraj nálezů středověkých skládacích vážek z českých zemí. In: Od knížat ke králům. Sborník u př́ležitosti 60. narozenin Josefa Žemličky (Doležalová, E.-Šimůnek, R., edd.), 147-157, 581-582. Praha. DOLISTA, K., 1971: Ještě k listinám hradištského kláštera z roku 1078, ČČH XIX, 111-118. 
DURDÍK, T., 2004: Nálezy z hradů přechodného typu (Hlavačov, Angerbach, Tachov). Praha.

- 2007: Hrady přechodného typu v Čechách. Praha.

ELBEL, P., 2002: Hospodářské zázemí kláštera Hradiště u Olomouce v 11. a 12. století. In: Jan, L.-Obšusta, P., Ve stopách sv. Benedikta. Sborník příspěvků z konference Středověké kláštery v zemích Koruny české konané ve dnech 24.-25. května 2001 v Třebíči, 39-56. Brno.

ETTLER, V. a kol., 2015: Ettler, V.-Johan, Z.-Zavřel, J.-Selmi-Wallisová, M.-Mihaljevič, M.-Šebek, O., Slag remains from the Na Slupi site (Prague, Czech Republic): Evidence for early medieval non-ferrous metal smelting, Journal of Archaeological Science 53, 72-83. https://doi.org/10.1016/j.jas.2014.10.007

FALTÝNEK, K.-NOVÁK, J.-ŠLÉZAR, P., 2018: Raně středověké osídlení v Moravičanech na Soutoku Early Middle Ages settlement in Moravičany at the Soutok, PV 59, č. 2, 119-159.

FERULÍK, A., 1950: Nálezová zpráva ke sbírce pravěkých nálezů z Knínic a okolí, odevzdaná r. 1949 městskému museu v Boskovicích Aloisem Ferulíkem, Z dávných věků II, 222-234.

FINGERLIN, I., 1971: Gürtel des hohen und späten Mittelalters. Berlin.

FROLÍK, J.-SIGL, J., 1998: Chrudim v pravěku a středověku. Obrázky každodenního života. Chrudim.

- 1998a: Poznámky k importům v Chrudimi a Hradci Králové - Befunde zu den „Importen“ in Chrudim und Hradec Králové, AH 23, 429-434.

FRB II: Fontes rerum Bohemicarum - Prameny dějin českých. Tomus II. (Emler, E.-Tomek, V. V., edd.). Praha $1874-1875$.

GALUŠKA, L., 2009: K otázce osídlení Starého Města - Veligradu v době po zániku Velké Moravy. Mladohradištní keramika z lokality „Na Zahrádkách“ - Zur Frage der Besiedelung von Staré Město-Veligrad in der Zeit nach dem Untergang Grossmähtrns. Jungburgwallzeitliche Keramik von der Fundstätte „Na Zahrádkách“, AH 34, 605-638.

GOŠ, V., 1970: K poznání vývoje mladohradištní keramiky na severní Moravě, SbNM A XXIV, 39-44.

- 1977: Slovanská keramika 10.-13. století na severní Moravě, VVM XXIX, 291-303.

- 1980: Wzajemne oddziaływanie północnych Moraw i Śląska we wczesnym średniowieczu na przykładzie znalezisk ceramiki, Silesia Antiqua 22, 159-174.

GOŠ, V.-KAPL, V., 1986: Slovanská osada u Palonína, okr. Šumperk, AR XXXVIII, 176-204.

GOŠ, V.-KAREL, J., 1979: Slovanské a středověké zásobnice severní Moravy, AR XXXI, 163-175.

GROSSMANNOVÁ, D.-VÍCH, D., 2014: Nález mincí z Křenova, Folia numismatica 28, 163-179.

HEINDEL, I., 1990: Riemen- und Gürtelteile im slawischen Siedlungsgebiet. Berlin.

HRDLIČKA, L.-RICHTER, M.-SMETÁNKA, Z., 1966: Výzkum v Sezimově Ústí v r. 1965, AR XVIII, 663-680.

HRUBÝ, P.-HEJHAL, P., 2011: Hornické a úpravnické areály na Českomoravské vrchovině a jejich vztah k soudobým městským centrům ve 13. století, Forum urbes medii aevi VI. Surovinová základna a její využití ve stř̌edověkém městě, $128-175$.

CHARVÁT, P., 1997: Hrady v podlesí: středověké Vraclavsko do roku 1300, Pomezí Čech a Moravy 1, 7-41.

JEŽEK, M., 2002: Odkrycia wag składanych w krajach czeskich. In: Civitas \& villa. Miasto i wieś w średniowiecznej Europie środkovej (Buśko, C.-Klápště, J.-Leciejewicz, L.-Moździoch, S., edd.), 453-456. Wrocław - Praha.

KLÁPŠTĚ, J., 1983: Studie o středověké studně z Mostu, PA LXXXIV, 443-492.

KOŠTA, J.-TOMKOVÁ, K., 2011: Olivovité korálky v raně středověkých Čechách a jejich postavení ve středoevropském kontextu, PA CII, 307-354.

KRABATH, S., 2001: Die hoch- und spätmittelalterlichen Buntmetallfunde nördlich der Alpen. Eine archäologisch-kunsthistorische Untersuchung zu ihrer Herstellungstechnik, funktionalen und zeitlichen Bestimmung. Internationale Archäologie 63. Rahden.

KRISTEN, Z., 1960: Známá-neznámá listina markraběte Přemysla pro moravské statky pražského biskupství z r. 1233, Zprávy Vlastivědného ústavu v Olomouci 88, 129-139.

KRUMPHANZLOVÁ, Z., 1965: Skleněné perly doby hradištní v Čechách, PA LVI, 161-188

MACKERLE, J., 1957: Provincie Úsobrnská. Severní Morava, Vlastivědný sborník, č. 2, 23-26.

- 1957a: Stará sídelní oblast severozápadní Moravy. Nepublikovaný rukopis, ulož. v archivu Archeologického ústavu AV ČR Brno. 
MACHÁČEK, K.-MĚCHURA, R., 2013: Raně středověké olovo z jižní Moravy a hutnické centrum na Slezsko-krakovské vysočině. In: Argenti fossores et alii. Znaczenie gospodarcze wschodnich części Górnego Śląska i zachodnich krańców Małopolski w późnej fazie wczesnego średniowiecza (X-XIII wiek) (Boroń, P., ed.), 275-287. Wrocław.

MACHÁŇOVÁ, L., 2007: Kovové nálezy z hornického sídliště 13.-14. století Jihlava - Staré Hory. In: Stř́ibrná Jihlava 2007. Studie k dějinám hornictví a důlních prací, Archeologické výzkumy na Vysočině Suplementum 1, 270-277. Jihlava - Brno.

- 2009: Kovové součásti středověkých oděvů získané archeologickými výzkumy v Jihlavě. In: Křižová, A., Ornament - oděv - šperk. Archaické projevy materiální kultury. Etnologické studie 5, 160-169. Brno.

MĚŘÍNSKÝ, Z., 1986: Morava v 10. století ve světle archeologických nálezů, PA LXXVII, 18-80.

MICHNA, P., 1977: Nowy przyczynek do poznania kontaktów polsko-morawskich we wczesnym średniowieczu, Acta Archaeologica Carpatica 17, 223-229.

- 1979: Středověké mincovní vážky z Olomouce - Die mittelalterliche Klappwaage aus Olmütz in Mähren, VVM XXXI, 38-48.

NOVOTNÝ, B., 1971: Staroslovanské výšinné hradisko Mařín u Křenova na Svitavsku, SPFFBU E 16, 217-223.

PRINCOVÁ-JUSTOVÁ, J., 1994: Die burgwallzeitliche Keramik aus Liboce nad Cidlinou. In: Slawische Keramik in Mitteleuropa vom 8. bis zum 11. Jahrhundert. Internationale Tagungen in Mikulčice I. (Staňa, Č., ed.), 193-205. Brno.

PROFANTOVÁ, N.-VÍCH, D., 2008: Raně středověké osídlení Malé Hané na pomezí Čech a Moravy, PV 49, 133-164.

PROCHÁZKA, R., 1984: Pozdně hradištní keramika v některých moravských regionech, AR XXXVI, 430-442.

- 1994: Svitávka - Hradisko v 11.-15. století, CB 4, 231-236.

- 2009: Moravská keramika kolem r. 1000 - otázka kontinuity a změny. In: S. Moździoch, Stare i nowe w średniowieczu: pomiędzy innowacją, 151-186. Wrocław.

- 2014: Raně středověké osídlení (2. pol. 6. století - 1200). In: Pravěk Boskovicka (Jarůšková, Z.-Štrof, A., edd.), 231-272. Boskovice.

- 2017: Hrad Přerov v raném středověku (9.-11. století) a počátky mladohradištní hmotné kultury (Archeologický výzkum na Horním náměstí, č. p. 8, 9 a 21). Brno.

PROCHÁZKA, R.-PEŠKA, M., 2007: Základní rysy vývoje brněnské keramiky ve 12.-13./14. století Grundlinien der Entwicklung der Keramik von Brno im 12.-13./14. Jahrhundert, PV 48, 143-299.

PROCHÁZKA, R.-ŠTROF, A., 1983: Příspěvek k osídlení Bořitova a Černé Hory na Blanensku, VVM XXXV, 46-58.

- 1987: Z badań nad kontaktami polsko-morawskimi we wczesnym średniowieczu, Silesia antiqua XXIX, 101-109.

RICHTER, M., 1963: Raně středověké bronzové skládací vážky z Čech - Frühmittelalterliche Bronzeklappwagen aus Böhmen. In: Sborník Československé společnosti archeologické (K problémům prehistorie na Moravě a v sousedních oblastech) 3 (Tichý, R., ed.), 141-148. Brno.

- 1982: Hradišt'ko u Davle. Městečko ostrovského kláštera. Praha.

RICHTER, M.-VOKOLEK, V., 1995: Hradec Králové. Slovanské hradiště a počátky středověkého města. Hradec Králové.

ROZMUS, D., 2016: Nowe znaleziska wczesnośredniowiecznych ciężarków ołowianych, Materiały Archeologiczne XLI, 263-272.

RUTTKAY, A., 1989: Prvky gotickej módy v odeve a ozdobách dedinského obyvatel'stva na území Slovenska (Horizont hrobov zo 14.-15. stor. v Ducovom, obec Moravany nad Váhom) - Elemente der gotischen Mode in Kleidung und Schmuck bei der ländlichen Bevölkerung auf dem Gebiet der Slowakei (Grabhorizont aus dem 14.-15. Jh. in Ducové, Gemeinde Moravany nad Váhom), AH 14, 355-378.

STAŇA, Č., 1994: Die Entwicklung der Keramik vom 8. bis zur Mitte des 11. Jahrhunderts in Mittelmähren. In: Slawische Keramik in Mitteleuropa vom 8. bis zum 11. Jahrhundert. Internationale Tagungen in Mikulčice I. (Staňa, Č., ed.), 265-286. Brno. 
- 1995: Př́íspěvek k poznání horizontu veligradského šperku, SPFFBU E 40, 37-45.

- 1998: Polské prvky v raně středověké keramice na Moravě. In: Kraje slowiańskie w wiekach średnich. Profanum i sacrum (Kóčka-Krenz, H.-Losiński, W., edd.), 273-287. Poznań.

STAŠŠÍKOVÁ-ŠTUKOVSKÁ, D.-UNGERMAN, Š., 2009: Sklené koráliky z včasnostredovekého pohrebiska v Dolních Věstonicích. In: Dresler, P.-Měřínský, Z., Archeologie doby hradištní v České a Slovenské republice. Sborník př́íspěvků přednesených na pracovním setkání Archeologie doby hradištní ve dnech 24.-26. 4. 2006, 136-149. Brno.

STEUER, H., 1997: Waagen und Gewichte aus dem mittelalterlichen Schleswig. Funde des 11. bis 13. Jahrhunderts aus Europa als Quellen zur Handels- und Währungsgeschichte. Köln.

ŠEMBERA, A. V., 1875: O úkladném útoku, jejž učinil Kunrat, kníže Znojemský, na Olomouckého biskupa Jindřicha Zdíka roku 1145, Časopis Musea Království českého XLIX, 47-81.

ŠLANCAROVÁ, V., 2018: Středověký šperk. Archeologické nálezy z jižní Moravy. Brno.

ŠLANCAROVÁ, V.-KŘÍŽZVÁ, A., 2009: Podoba středověkého šperku (s přihlédnutím ke sbírkám a nálezům na jižní Moravě). In: Kř́žová, A., Ornament - oděv - šperk. Archaické projevy materiální kultury. Etnologické studie 5, 141-159. Brno.

ŠLÉZAR, P., 2014: Nové poznatky k raně středověké fortifikaci „Hradisko nad Nectavou“ na katastru obce Biskupice u Jevíčka. Historica Olomucensia - Supplementum II, 75-90. Olomouc.

ŠLÉZAR, P.-FALTÝNEK, K., 2019: Románský kostel sv. Prokopa v Lošticích. Př́ispěvek k počátkům moravské šlechty - The Romanesque church of St. Procopius in Loštice. Contribution to the beginnings of Moravian aristocracy, PV 60, č. 2, 161-199.

ŠTEFAN, I., 2010: Př́íspěvek k chronologii a výpovědním možnostem esovitých záušnic, Studia Mediaevalia Pragensia 9, 171-205.

ŠTROF, A., 1979: Pravěké osídlení Lysické sníženiny a Malé Hané na základě nálezů hmotné kultury I-III. Nepublikovaná diplomová práce, ulož. na FF MU, Brno.

- 1985: Übersicht neuer Lokalitäten und Funde in der Boskovicer Furche (Bez. Blansko), PV 1983, 91-98.

TABAKA, A., 2005: Domniemane miejsce targowe na Ostrowie Lednickim, Studia Lednickie VII, 131-144.

TOMKOVÁ, K., 2005: Hmotná kultura raně středověkých pohřebišt' Pražského hradu a jeho předpolí. Pohřbívání na Pražském hradě a jeho předpolích. Díl I.1. In: Castrum Pragense 7 (Tomková, K., ed.), 217-304. Praha.

UNGERMAN, Š., 2010: Počátky mladohradištních pohřebišt’ na Moravě. In: Zaměřeno na středověk. Zdeňkovi Měřínskému k 60. narozeninám, 220-239. Praha.

VÁVRA, I., 1971: Trstenická stezka, HG 6, 77-132.

VIDEMAN, J., 2017: K postavení tzv. imitativních ražeb v počátcích českého (a moravského) mincovnictví v 10. století, Numismatické listy $72,10-25$.

- 2018: Finds of Coins and the Beginnings of Minting in Moravia in the Tenth and Early Eleventh Centuries. In: Kouřil, P.-Procházka, R., Moravian and Silesian Strongholds of the Tenth and Eleventh Centuries in the Context of Central Europe, 215-228. Brno.

VIDEMAN, J.-VÍCH, D., 2015: Moravské denáry Vratislava II. a Oty III. Dětleba z Chornice (okr. Svitavy), Numismatický sborník 29, 261-265.

- 2020: Nález dvou mincí denárového období od Jevíčka na Malé Hané, Denarius 8, 56-58.

VÍCH, D., 2001: Povrchová prospekce severní části Boskovické brázdy v letech 1997-2000, Zpravodaj muzea v Hradci Králové 27, 27-56.

- 2015: Příspěvek k metodice detektorové prospekce v archeologii, AVČ 7 (2014), 152-172.

- 2018: Relikty zaniklých cest mezi Křenovem a Hradcem nad Svitavou na Svitavsku ve světle archeologických nálezů, AVČ 12 (2016), 56-75.

VÍCH, D.-ŽÁKOVSKÝ, P., 2016: Vojenské vybavení bojové družiny před husitskou revolucí. Soubor militarií z hradu Orlík u Brandýsa nad Orlicí ve východních Čechách, PA CVII, 279-351.

WACHOWSKI, K., 1974: Wagi i odvażniki na Śląsku wczesnośredniowiecznym na tle porównawczym Waagen und Gewichte in frühmettelalerlichen Schlesien, ein Vergleichstudium, Przegląd Archeologiczny $22,173-207$.

- 1994: Profilierte Schnallen im Mittelosteuropa, Zeitschrift für Archäologie des Mittelalters 22, 181-186. 
WIECZOREK, A.-HINZ, H.-M. et al., 2000: Europas Mitte um 1000. Katalog. Stuttgart.

WIHODA, M., 2002: Benediktinská kapitola v dějinách kláštera Hradisko u Olomouce. In: Jan, L.-Obšusta, P., Ve stopách sv. Benedikta. Sborník příspěvků z konference Středověké kláštery v zemích Koruny české konané ve dnech 24.-25. května 2001 v Třebíči, 29-38. Brno.

ZAORAL, P., 1968: K zakládací listině hradišt'ského kláštera z roku 1078, ČČH XVI, 275-283.

ZIMOLA, D.-VOKÁČ, M., 2011: Archeologické výzkumy několika venkovských kostelů na Jihlavsku Ländliche Sakralarchitektur in der Region Jihlava, AH 36, 431-453.

ŽÁKOVSKÝ, P.-HOŠEK, J., 2015: Kovové artefakty. In: Veselí nad Moravou. Středověký hrad v říční nivě, 220-251. Brno.

\section{Zusammenfassung}

\section{Der nördliche Teil der Region Malá Haná in durch Oberflächenprospektion entdeckten archäologischen Quellen des 11.-13. Jahrhunderts}

Die Region Malá Haná ist ein langfristig besiedeltes Gebiet, das in den schriftlichen Quellen erstmals im Jahr 1078 im Rahmen der Gründungsurkunde von Kloster Hradisch bei Olmütz (Hradisko, Hradiště) auftritt. Die archäologischen Erkenntnisse über das 11.-13. Jahrhundert standen dort jedoch lange am Rande des Interesses, gewisse neue Informationen liefert eine an die Arbeiten der Vorgänger (A. Ferulík, J. Mackerle, A. Štrof) anknüpfende Oberflächenprospektion, die dort vom Verfasser seit 1997 (Oberflächensammlung), bzw. 2005 (Detektorsuche) durchgeführt wurde.

Bzgl. des Interessensgebiets verfügen wir vor allem über einen Keramikkomplex (Abb. 1-4), ergänzt von zahllosen Metallartefakten (Abb. 5) und einer Glasperle (Abb. 7). Die häufig Graphit enthaltende Keramik repräsentiert die charakteristische jungburgwallzeitliche Produktion. Mit einem Exemplar vertreten ist ein Gefäßrand mit Zylinderhals (Abb. 1:29).

Die Metallindustrie der Jungburgwallzeit wird durch s-förmige Schläfenringe (Abb. 5:3-4) und Bleirädchen mit Mittelloch (Abb. 5:2, 16, 18) repräsentiert, zum 13. Jahrhundert gehören Bronzeschnallen (Abb. 5:1, 5-7, 9-11, 14), lilienförmige Gürtebeschläge (Abb. 5:12-13, 15, 17), die auch aus der nahegelegenen Region Svitavsko bekannt sind (Abb. 6), und Balkenfragmente einer Klappwaage (Abb. 5:8).

Ein Vertreter von den Glasartefakten aus dem im Interessensgebiet beobachteten Zeitraum ist eine ellipsenförmige längs gegliederte Perle von der Fundstelle Biskupice 4c, die aus blauem intransparenten Glas hergestellt wurde und olivförmigen Perlen zugeordnet werden kann (Abb. 7).

Die zum jüngeren Abschnitt des Frühmittelalters präsentierten Quellen aus dem nördlichen Teil der Boskowitzer Furche liefern auch trotz nur begrenzter Aussagefähigkeit einige interessante Feststellungen.

Die Anwesenheit des Menschen in der Region Malá Hana ist insbesondere in ihrem nördlichen Teil für den jüngeren Abschnitt des Frühmittelalters aufgrund der Aussagen der archäologischen Quellen aus dem 10. bzw. der ersten Hälfte des 11. Jahrhunderts unter Anknüpfung an das ältere Substrat belegt. Allerdings tauchen auch Siedlungen aus der Jungburgwallzeit ohne vorherige Entwicklung auf, die im Laufe des 13. Jahrhunderts wieder verschwinden. Obwohl die hier präsentierten Informationen über die Kontinuität/Diskontinuität der Besiedelung ausschließlich auf Quellen basieren, die durch landwirtschaftliche Tätigkeit aus ihrem ursprünglichen Kontext gerissen wurden, verzeichnen wir in der Besiedelung dem bisherigen Erkenntnisstand nach gleichwohl einen gewissen Scheidepunkt irgendwann im Zeitraum des 10. bis zur ersten Hälfte des 11. Jahrhunderts, als an den meisten Fundstellen die Besiedelung endet, bzw. wir nicht dazu in der Lage sind, ihre Fortsetzung archäologisch zu erfassen.

Das Ausmaß der Besiedelung im jüngeren Abschnitt des Frühmittelalters kopiert die ältere Situation aus der Mittelburgwallzeit, als die Besiedelung in nördlicher Richtung an der 
heutigen Nordgrenze des Katastergebiets Chornice aufhörte (Abb. 8). Zu einer flächendeckenden Besiedelung des Interessensgebietes und offenbar auch zu einer gewissen Stabilisierung des Siedlungsnetzes kommt es demnach bereits zur Zeit Großmährens. Das nördlich von der Region Malá Haná liegende Gebiet ist gemäß dem aktuellen Kenntnisstand den archäologischen Quellen nach und trotz lokalen Vorkommens der vom Menschen bereits in der Urzeit genutzten fruchtbaren Böden (Umgebung von Staré Město bei Moravská Třebová) erst im Laufe des 13. Jahrhunderts kolonisiert worden (Abb. 9), was auch für die nahegelegene Region Svitavsko gilt (Fund lilienförmiger Gürtelbeschläge aus Březová nad Svitavou, Abb. 6). Die Jungburgwallzeit tritt, was die Ausdehnung des besetzten Gebietes betrifft, in dieser Hinsicht demnach als Zeitraum einer gewissen Stagnation in Erscheinung. Wir können ein inselhaftes Vordringen von Kolonisten in unbesiedelte Gebiete bereits im 11. bzw. eher im 12. Jahrhundert zwar nicht ausschließen, jedoch sind die derzeitigen Belege dafür jedoch mehr als nur vereinzelt und entbehren als alte Funde zuverlässige Fundumstände, auch können wir das Risiko einer Vermischung der Funde in den musealen Sammlungen nicht ausschließen.

Die neuen Funde von Metallgegenständen stellen die gängige Sachkultur jener Zeit dar, lediglich Münzen belegen, wenn sie auch vorerst nur sporadisch vorkommen, die Verfügbarkeit von Prägemetall. Überraschend und bislang nur schwer erklärbar bleibt das Vorkommen eines Belegs für Handelstätigkeit in Form eines Klappwaagenfragmentes aus Chornice in ländlicher Umgebung. Frage und Aufgabe der weiteren Forschung ist bis auf weiteres, ob die Funde der Bleirädchen mit Mittelloch mit dem Handel zusammenhängen.

PhDr. David Vích, Regionální muzeum ve Vysokém Mýtě, A. V. Šembery 125, 56601 Vysoké Mýto, Česká republika,dvich@centrum.cz 
